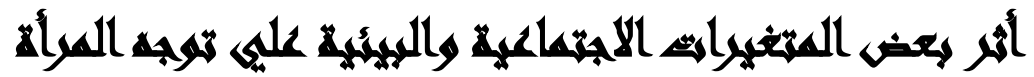

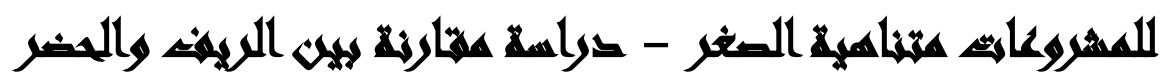

حنان كامل فريد (')- صالح سليمان عبد العظيم(ץ)- نجلاء محمود مصلحي(r)

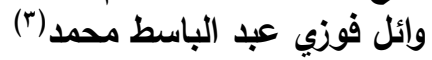

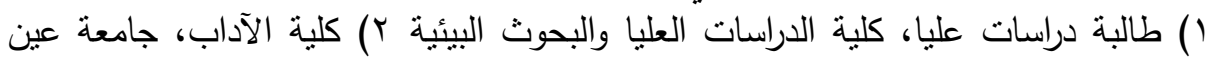
شمس ץ) كلية التجارة، جامعة عين شمس.

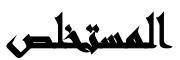

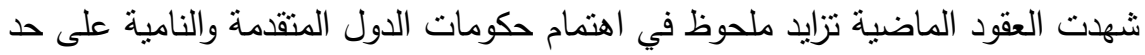

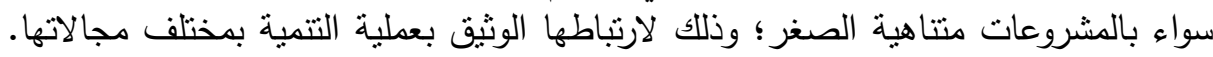



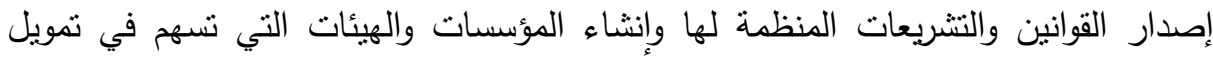
ودعم تلاك المشروعات.

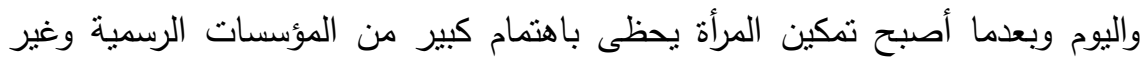

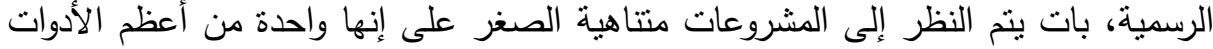

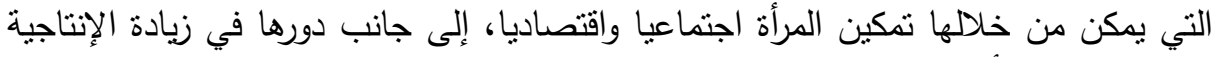

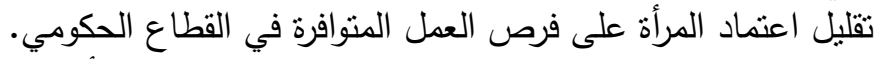

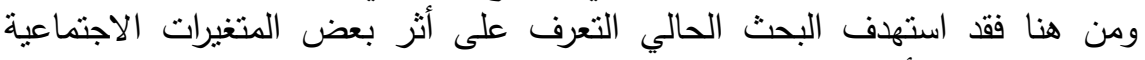

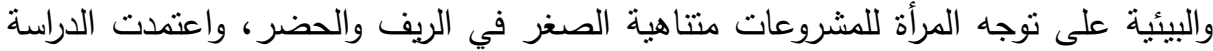

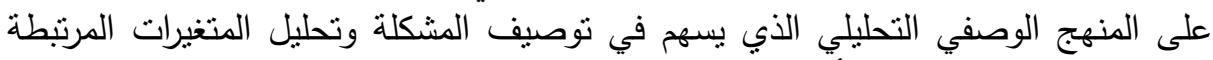

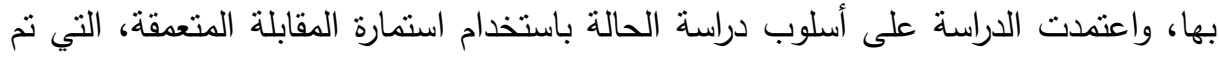

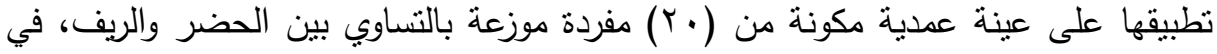

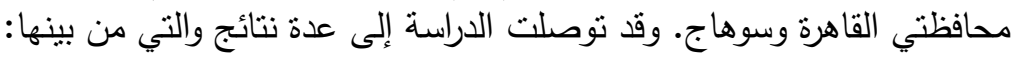

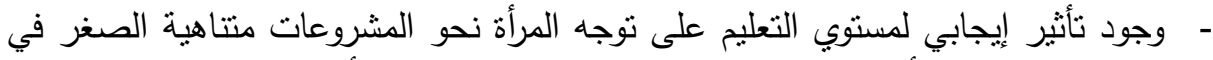



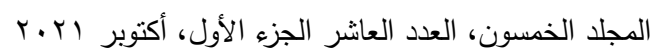

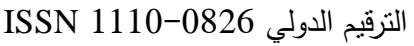

$$
\begin{aligned}
& \text { الترقيم الدولي الموحد الإلكتروني 3178-2636-26 التروب }
\end{aligned}
$$


وأثنارت الدراسة إلى وجود علاقة ارتباطية كذلك بين العمر ومستوى الدخل والحالة الأله

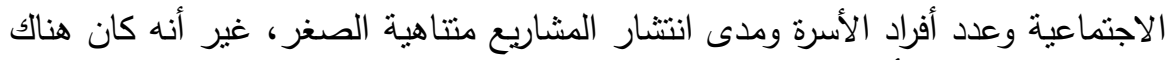

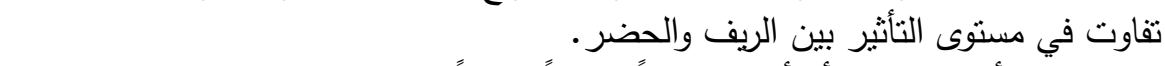



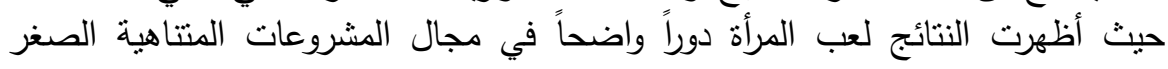
والصغيرة.

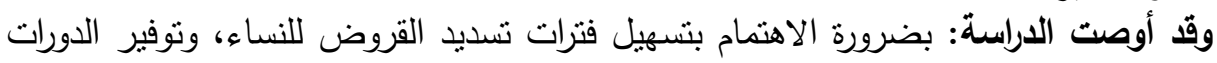


ممنلة في المجالس المحلية خاصة في الريف.

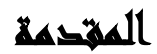

شهدت السنوات الماضية سلسلة من التغيرات على المستوى الاجتماعي، والتي أثرت

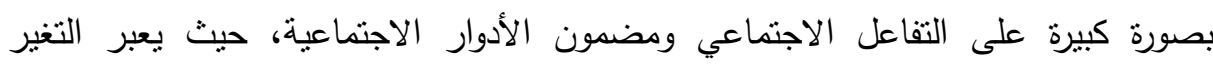

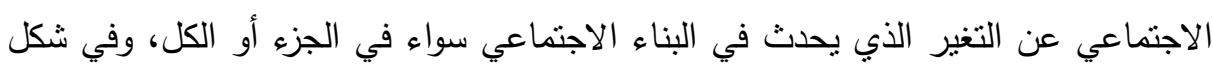

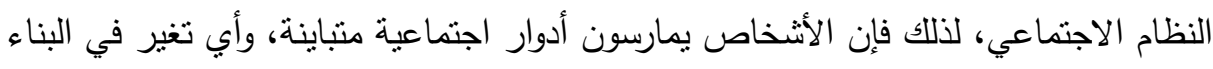
الاجتماعي يمكن ملاحظته في وقت زمني قصير بين فئات كبيرة من المجتمع، ويعمل على التئي

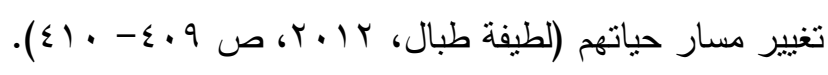

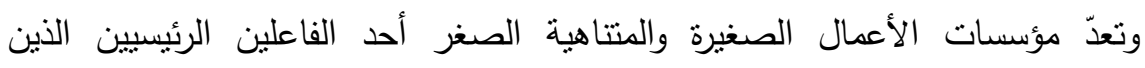

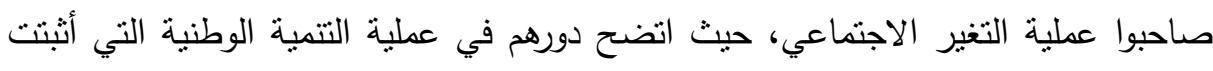

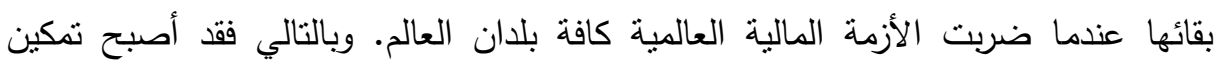

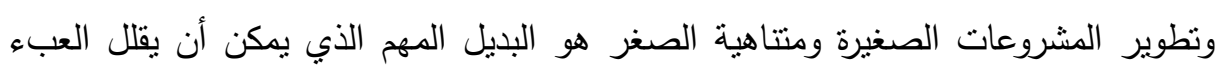

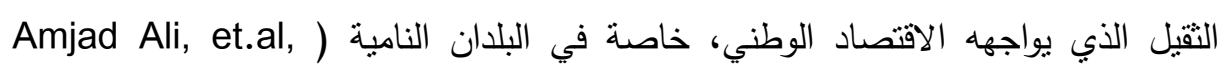
. $(2014$, p. 24

$$
\begin{aligned}
& \text { المجلد الخمسون، العدد العاثر الجزء الأول، أكتوبر ابr.r. }
\end{aligned}
$$

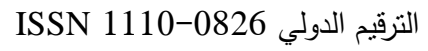

$$
\begin{aligned}
& \text { الترقيم الدولي الموحد الإلكتروني 3178-2636-26 }
\end{aligned}
$$


ويشير مفهوم المشروعات الصغيرة، وفقاً للبنك المركزي المصري إلى المشروعات التي اعمات لا يتخطى حجم أعمالها في العام الواحد عن مليون جنية مصري، وتبعا للشركات حديثة النشأة

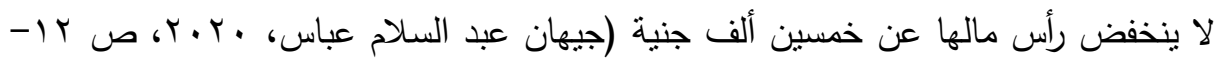
r (). بينما الثركات صغيرة الحجم تتطلب أن يتخذ شخص أو شخصين جميع القرارات الإدارية الحاسمة (Gordon Hunter\& Dan Kazakoff, 2014, p.19-20). وقد أثنارت الدراسات إلى أهية هذه المشروعات بالنسبة للمرأة؛ موضحين أنه عندما تتمتع المرأة بالقدرة على الإنفاق عبر امتلاك مشروع صغير أو متتاهي الصغر فإنها تتمتع التهاه

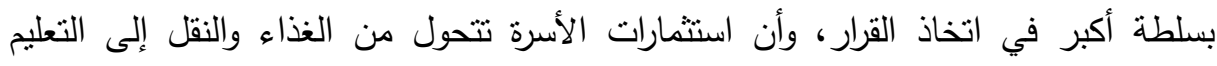
والرعاية الطبية، وأنه في كل من المناطق الحضرية والريفية، تتفق الأسر أكثر على التعليم عندما يكون للمرأة مصدر للاخل (Nurul Asfiah, 2018, p.67). ومن هنا يجب التأكيد على أنه لا يمكن لأي مجتمع أن يسير في طريق التنمية الثشاملة

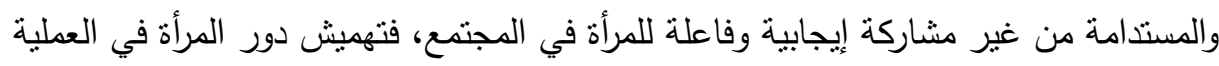

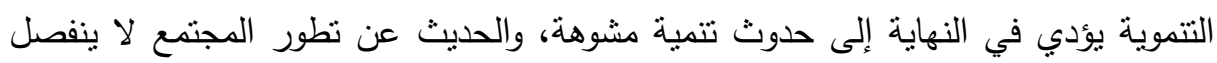
عن النهوض بدور المرأة وإشراكها في عملية التتمية الاقتصادية. وبناء على ما سبق تستهدف الدراسة الحالية التعرف على أثز المتغيرات الاجتماعية

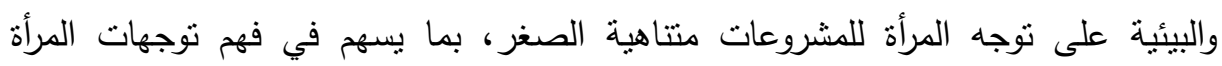
وطبيعة الأنشطة التي تقوم بها في المجتمع الحضري والريفي.

$$
\begin{aligned}
& \text { المجلد الخمسون، العدد العاشر الجزء الأول، أكتوبر ب.r.r. }
\end{aligned}
$$

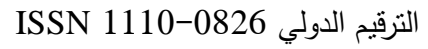

$$
\begin{aligned}
& \text { الترقيم الدولي الموحد الإلكتروني 3178-2636-26 }
\end{aligned}
$$




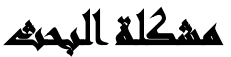

أثشارت عدة دراسات إلى أهمية المشروعات الصغيرة ومتتاهية الصغر، خاصة فيما يتعلق بتأثثراتها الإيجابية على المرأة، حيث أثنارت دراسة (Jasika Alam Jitu, 2019)

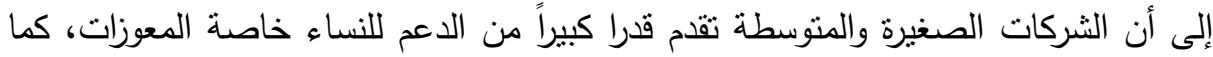
تسهم في تحقيق التمكين الاقتصادي للمرأة، وأن المشاريع الصغيرة والمتوسطة التي تملكها المرأة نسهم -إلى حد كبير - في دعم عدد من القضايا الاجتماعية والسياسية والبيئية المرنبطة

وفيما يتعلق بالثأن المصري أنشار (Tamer Mansour \& et.al, 2019) إلى أن

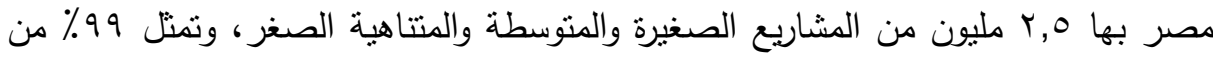

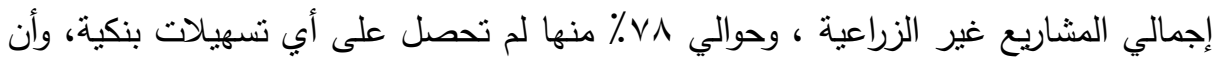

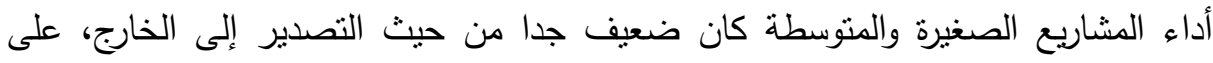
الرغم من الدور القوي الذي يمكن للشركات الصغيرة والمتوسطة أن تلعبه في عملية تسريع النتمية لأنها لا تتطلب استثمارات ضخمة، وقادرة كذلك على زيادة فرص العمل وتعبئة المدخرات الفردية الصغيرة ، وكذلك المساعدة في إعداد الكوادر الفنية. وفي دراسة (Rym Ayadi \& et.al, 2017) أنشار إلى إن استمرار ارتفاع معدلات

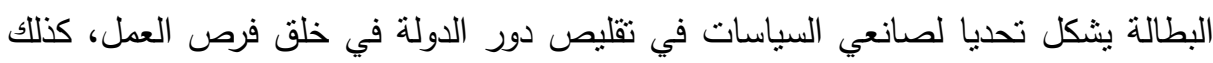

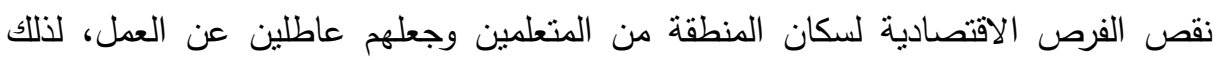
أكدت الدراسة على إن المشروعات المتتاهية الصغر والصغيرة والمتوسطة أصبحت أولوية الصنية سياسية في دول شرق وجنوب البحر المتوسط التي تعاني من البطالة. واتفقت دراسة (Hala El-Said, et.al 2014) مع ما نوصلت إليه النتائج السابقة وأشارت إلى أن المؤسسات الصغيرة والمتوسطة الحجم تمثل قوة ديناميكية للنمو الاقتصادي 78

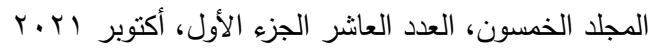

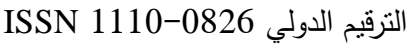

$$
\begin{aligned}
& \text { التزقيم الدولي الموحد الإلكتروني 3178-2636-26 }
\end{aligned}
$$


المستدام، كما نسهم في خلق فرص عمل في البلان النامية بشكل عام، وفي مصر بشكل



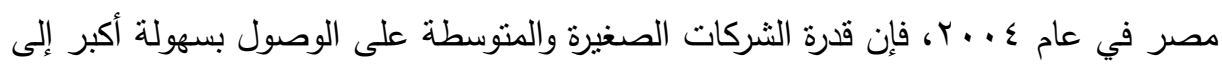

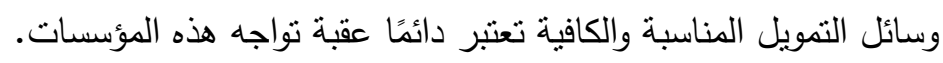
ومن هنا تهنم الدراسة الحالية بتحليل بعض المتغيرات البيئية والاجنماعية وأثرها علي دئي توجه المرأة للمشروعات متتاهية الصغر وعلاقة هذه المتغيرات بهذا التوجه، وذلك من خلال



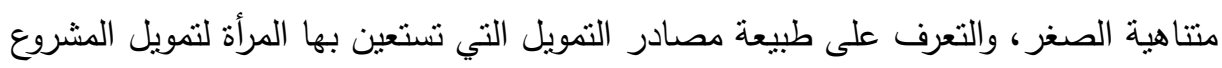
الخاص بها سواء في الريف أو الحضر.

\section{تمساولاهي المهمث}

في ضوء مشكلة البحث، تم وضع مجموعة من التساؤلات وهي:

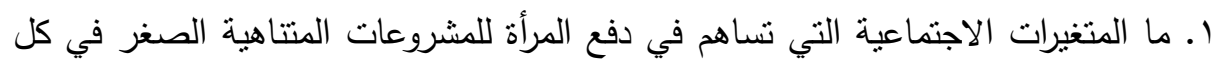

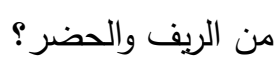
r. ما المتغيرات البيئية التي نساهم في دفع المرأة للمشروعات المتتاهية الصغر في كل من

$$
\text { الريف والحضر؟ مأغيرات }
$$

r. ما دور المشروعات المتتاهية الصغر في تمكين المرأة في مجتمعها في كل من الريف والحضر؟

ع. ما المعوقات التي نواجه الششروعات المتتاهية الصغر في كل من الريف والحضر؟

ه. ما دور المشروعات المتتاهية الصغر في تتمية المرأة إقتصاديا؟

7. ما تأثنر المشروعات المتتاهية الصغر في تتمية المرأة ذاتيا؟

$$
\begin{aligned}
& \text { المجلد الخمسون، العدد العانشر الجزء الأول، أكتوبر ابr.r } \\
& \text { الترقيم الدولي 0826- ISSN 1110 } \\
& \text { الترقيم الدولي الموحد الإكتروني 3178-2636 }
\end{aligned}
$$




$$
\begin{aligned}
& \text { مجلة العلوم البيئية } \\
& \text { كلية الدراسات العليا والبحوث البيئية - جامعة عين شمس لئية } \\
& \text { حنان كامل فريد وآخرون }
\end{aligned}
$$

V. ما تأثير المشروعات المتتاهية الصغر في تتمية المرأة اجتماعبا؟

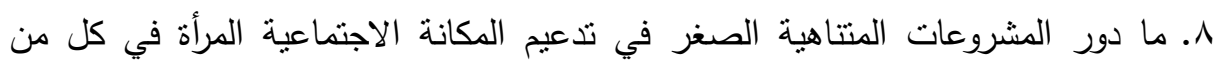

$$
\text { الريف والحضر؟ }
$$

\section{أهمية المهمث}

الأهمية النظرية: حاول البحث الإستفادة من التراث النظري لجميع الأدبيات المكتوبة عن

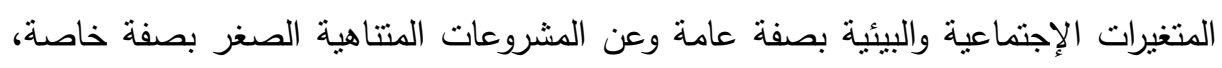
وذللك بشكل يخدم موضوع البحث للتعرف على أوجه الإتفاق والإختلاف بين الدراسات السابقة في هذا الدجال ولكن يلاحظ أنه لم يتطرق أحد إلى التعرف على التنغيرات الإجتماعية والبيئية

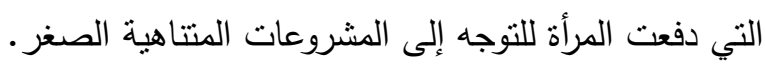
الأهمية التطبيقية: على الجانب التطبيقي حاول البحث التعرف على المتغيرات الإجتماعية والبيئية التي تذفع المرأة للتوجه إلى المشروعات المنتاهية الصغر وذلك في منطقة الدراسة

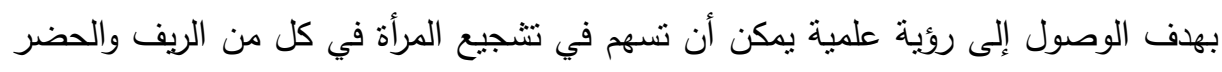

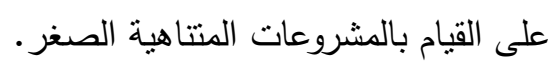
كما حاول البحث الراهن فتح مجالات وآفاق مختلفة للعاملين في مجال البحث الإجنماعي

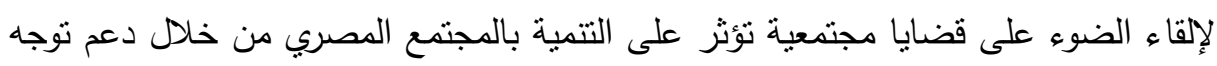
المرأة للمشروعات المتتاهية الصغر بكل من الريف والحضر .

$$
\begin{aligned}
& \text { المجلد الخمسون، العدد العاثر الجزء الأول، أكتوبر ابr.r. }
\end{aligned}
$$

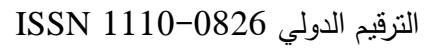

$$
\begin{aligned}
& \text { الترقيم الدولي الموحد الإلكتروني 3178-2636-26 التربي }
\end{aligned}
$$


مجلة العلوم البيئية

كلية الدراسات العليا والبحوث البيئية - جامعة عين شمس لئن

حنان كامل فريد وآخرون

\section{أهفا اهض المهمث}

\section{استهذف البحث الحالي التعرف على:}

• المتغيرات البيئية بمجتمع الدراسة (في كل من الريف والحضر) التي تساهم في دفع المرأة

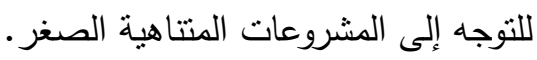

• المتغيرات الإجتماعية (في كل من الريف والحضر) التي تساهم في دفع المرأة للتوجه إلى الى الى

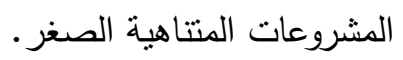

• المشكلات البيئية التي تواجه المرأة في كل من الريف والحضر في مجتمع الدراسة.

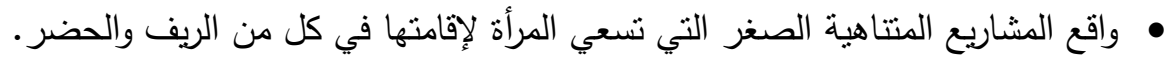

• المعوقات التي تواجه المرأة في مجال المشروعات المتتاهية الصغر في مجتمع الدراسة.

\section{هماهميه الهمهي}

تعدّ المصطلحات والمفاهيم العلمية أمراً ضرورياً في البحث العلمي عند صباغة أي البهاي

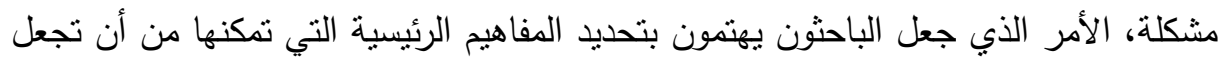
الروئة العلمية أكثر دقة وموضوعية في مجال البحث العلمي: المشروعات متناهية الصغر: تثشير منظمة العمل الدولية إلى إن المشروعات الصغيه لهيرة

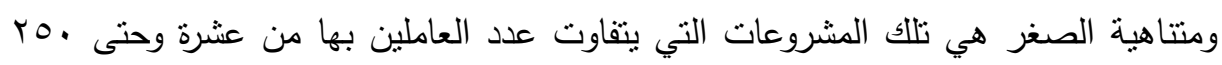

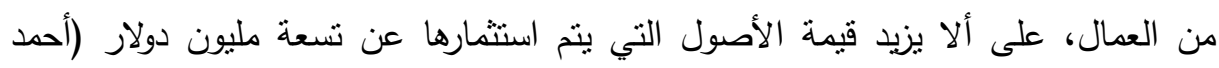

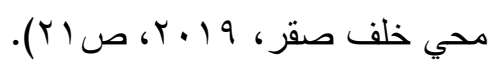

تعرف المشروعات متتاهية الصغر وفقا للاتحاد الأوروبي بكونها نلك المشروعات التي

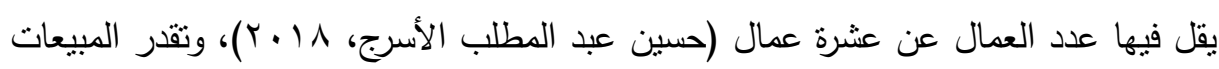

$$
\begin{aligned}
& \text { المجلد الخمسون، العدد العاثر الجزء الأول، أكتوبر ابr.r. } \\
& \text { الترقيم الدولي 0826- ISSN 1110 } \\
& \text { الترقيم الدولي الموحد الإكتروني 3178-2636 }
\end{aligned}
$$


السنوية بحوالي مائة ألف دولار وييلغ إجمالي الأصول حوالي عشرة آلاف دولار (اعتماد

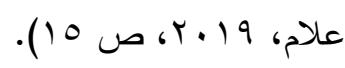

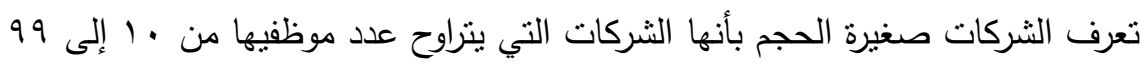

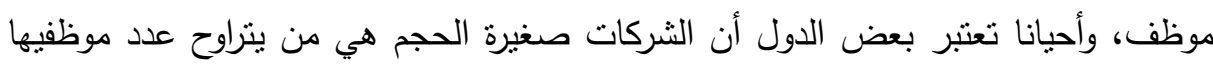

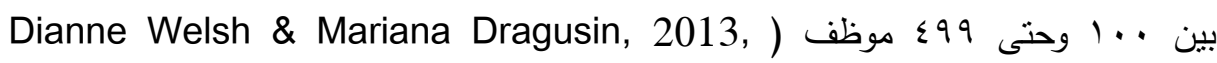
(P.37

مفهوم الحضر : تختلف مفاهيم الحضر بشكل كبير، حيث بنسم ذلك التعريف بالغموض، فيراه



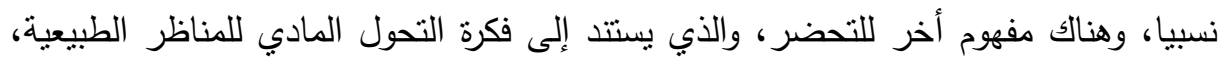

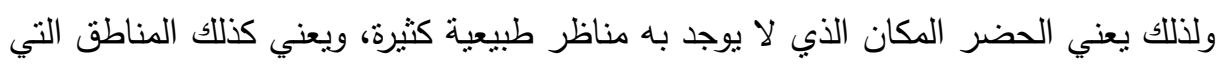

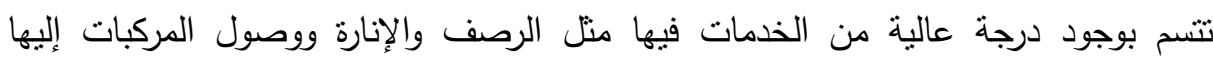

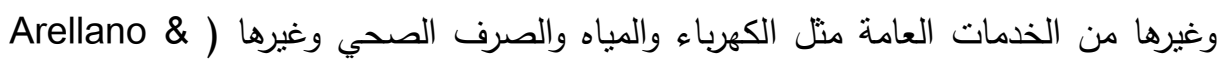
.(Roca, 2017, p5

يقصد بمفهوم الحضر الأثخاص الذين يعيشون في أماكن يوجد لها شكل محدد من

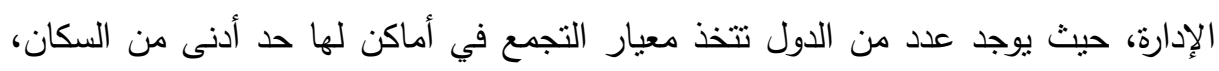

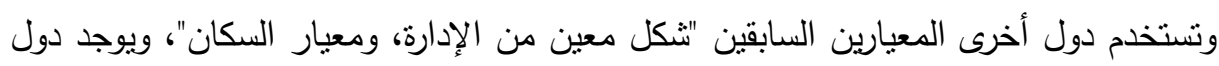

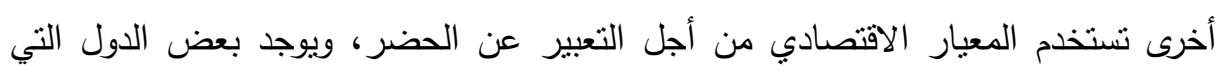

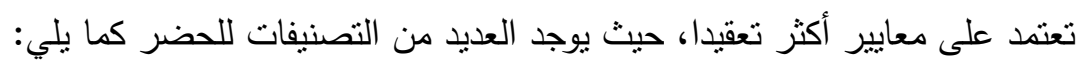

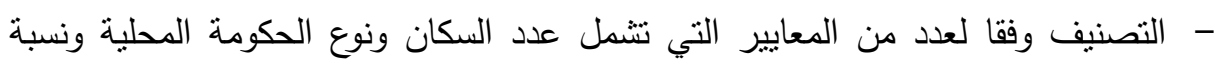
السكان الذين يعملون في الزراعة. - التتصيف وفقا لمعايير الإدارة.

$$
\begin{aligned}
& \text { المجلد الخمسون، العدد العاثر الجزء الأول، أكتوبر ابr.r. }
\end{aligned}
$$

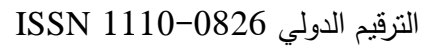

$$
\begin{aligned}
& \text { الترقيم الدولي الموحد الإلكتروني 3178-2636-26 }
\end{aligned}
$$




$$
\text { - التصنيف وفقا لمعيار الحجم السكاني. }
$$

تختلف مفاهيم الحضر من دولة لأخرى، حيث لا يوجد إجماع أكاديمي حول مفهوم التحضر، فمن الصعب وجود أي قاعدة بيانات عالمية يمكن من خلالها مقارنة مفاهيم

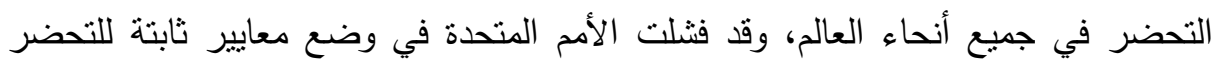

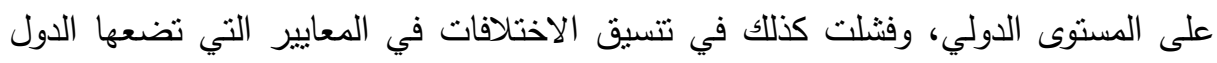

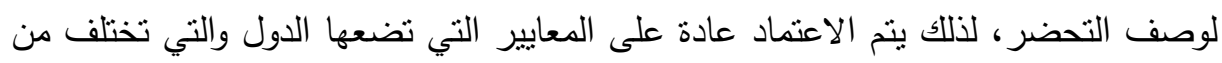



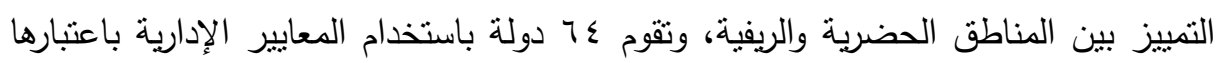

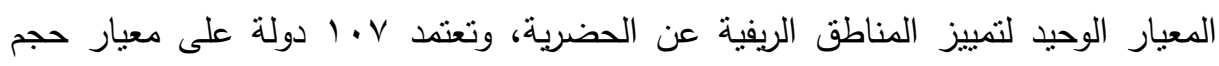
السكان أو الكثافة السكانية لتمييز الريف عن الحضر، وبعضيز الدضن الدول تعتمد على المعيار

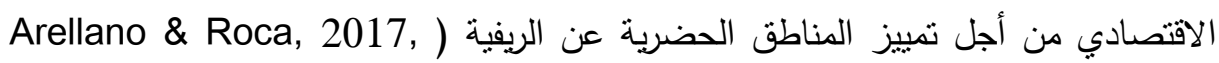

ويتم تعريف الحضر باعتباره مستوطنة كبيرة ويوجد بها وظائف مركزية وإدارية معينة، وتسير الأمور فيها وفقا لأوضاع قانونية ووطنية عصرية وحديثة، وعادة ما تقل نسبة الأراضي مبني

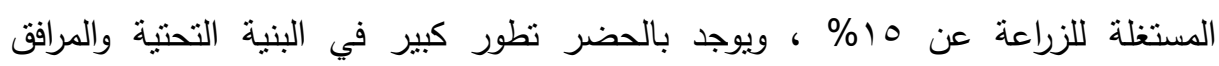

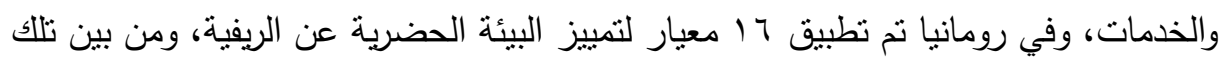
المعايير حجم السكان والمرافق الحضرية مثل المؤسسات والخدمات، والسمات البشرية، وأماكن

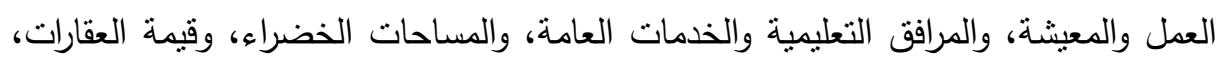
ويوجد للحضر خصائص شخصية عادة ما يتصف بها الأشخاص الذين يسكنون الحضر، واهرات

$$
\begin{aligned}
& \text { المجلد الخمسون، العدد العانشر الجزء الأول، أكتوبر ابr.r } \\
& \text { الترقيم الدولي 0826- ISSN 1110 } \\
& \text { الترقيم الدولي الموحد الإلكتروني 3178-2636 }
\end{aligned}
$$




\section{مجلة العلوم البيئية \\ كلية الدراسات العليا والبحوث البيئية - جامعة عين شمس لئن \\ حنان كامل فريد وآخرون}

Kovacs, ) حيث تسمى سمات ثقافية لقاطني الحضر ، ويوجد للمباني سمات معمارية أيضا .(2014, p 76

مفهوم الريف: يقصد بالريف المناطق التي يوجد بها مساحات خضراء شاسعة، والمناظر

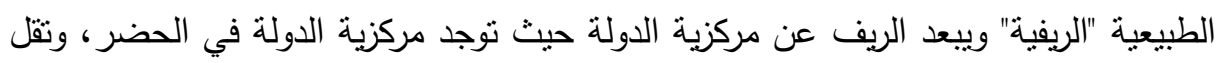

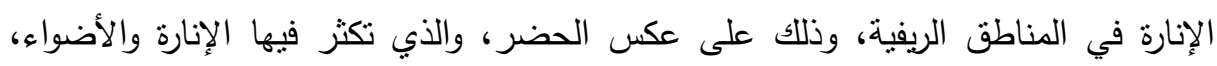

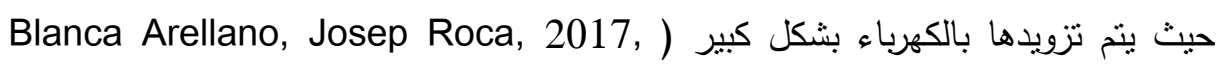
.(p6-7

ويقصد كذلك بالريف المكان الذي يبعد عن مركزية الدولة، وتكثر به الأنشطة الزراعية،

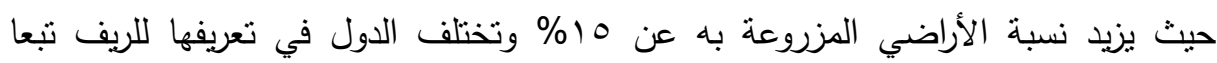
لمعايير مختلفة (Kovacs, 2014, p 76). المتغيرات الإجتماعية والبيئية: هي مجموعة من العوامل التي تسهم في تتكيل شخصية الفرد

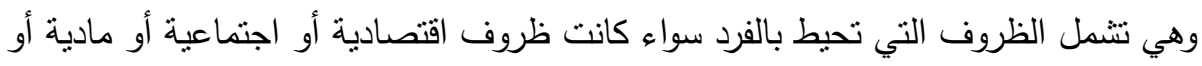
نفسية فيتعلم الفرد منها القيم والمبادئ والعادات والتقاليد ويعرف التغير الاجتماعي بكونه التتمية المنظمة التي تحدث في المجتمع أو ثقافته في إطار معين، ويمكن تعريف التغير الاجتماعي بشكل أكبر على أساس عدد من الأبعاد

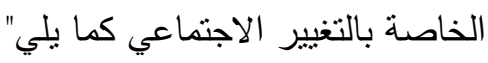
- بعد المكان: والذي يتمثل في مكان حدوث التغيير سواء كان (جزئي، أو متوسط، أو كلي) - بعد الوقت: ويتمنل في الوقت الذي يحدث فيه التغيير، سواء كان ذلك الوقت قصير أو

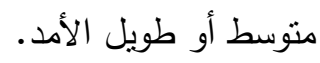

$$
\begin{aligned}
& \text { المجلد الخمسون، العدد العاثر الجزء الأول، أكتوبر ابr.r. }
\end{aligned}
$$

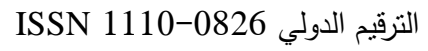

$$
\begin{aligned}
& \text { الترقيم الدولي الموحد الإلكتروني 3178-2636-26 التربي }
\end{aligned}
$$


- بعد السرعة: وتتمنل في السرعة التي يحدث فيها النطور من حيث كونه تغير بطيء أم

$$
\text { تدريجي أو تصاعدي سريع أو ثوري. }
$$

- بعد الاتجاه: هو اتجاه حدوث التغيير إلى الإمام أو إلى الخلف. نورئ.

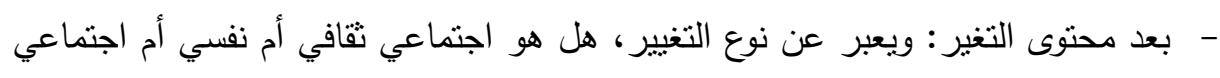
أم تتظيمي أم اقتصادي أم أنثروبولوجي.

Servaes, ) تأثير التغير الاجتماعي: ويتم تحديده إذا ما كان تغير سلمي أم تغير عنيف أنيف .(2011, p 1-2

كذلك هي التحولات التي تطرأ على أنماط التنظيم الاجتماعي، والتي بنتج عنها تغيير في

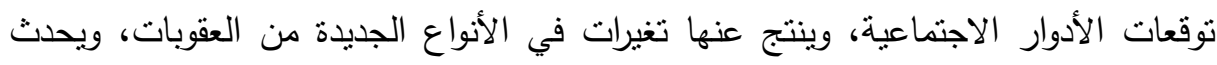

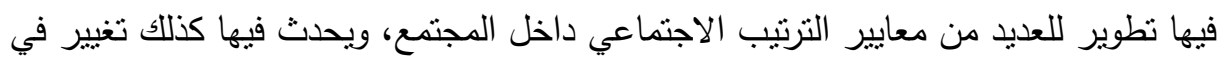

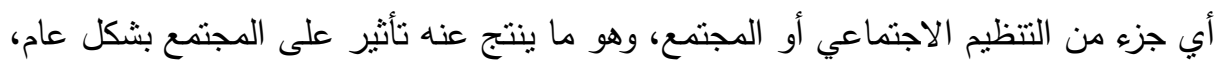

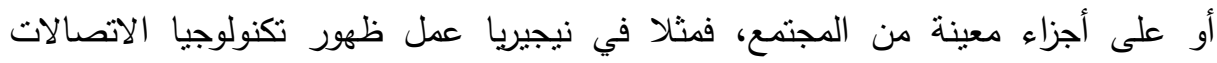

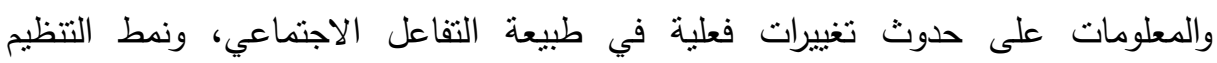
الاجتماعي، وعمل الإنترنت على حدوث تغيير في القطاع الاقتصادي منل الخدمات المصرفية الإكترونية والتجارية الإلكترونية، وقد أثز ذلك على التعليم الإلكتروني، لذلكئ يعرف

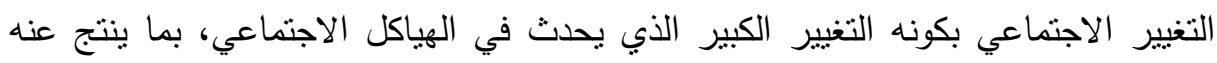

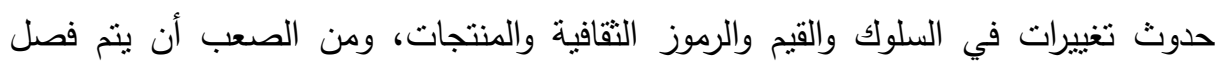

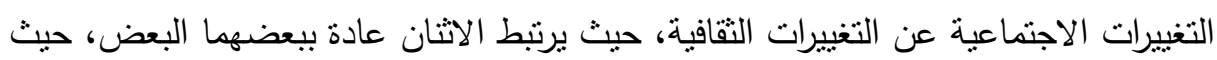
Theophilus C Akujobi, ينتج عن التغيير الاجتماعي تغيير ثقافي والعكس صحيح

$$
\begin{aligned}
& \text { المجلد الخمسون، العدد العاشر الجزء الأول، أكتوبر ب.r.r. }
\end{aligned}
$$

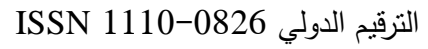

$$
\begin{aligned}
& \text { الترقيم الدولي الموحد الإلكتروني 3178-2636-26 التروب }
\end{aligned}
$$




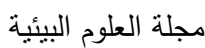

كلية الدراسات العليا والبحوث البيئة - جامعة عين شمس لئية

حنان كامل فريد وآخرون

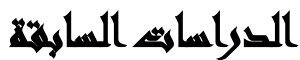

بعد مراجعة التزاث العلمي في مجال الدراسة الحالية تم تقسم الدراسات السابقة إلى دراسات عربية وأخرى أجنبية، وذلك كما يلي: لئي

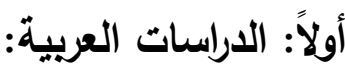

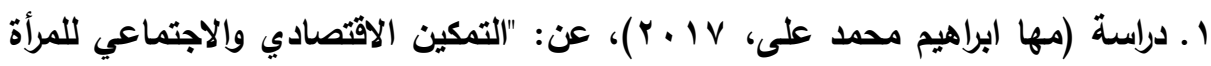
المعيلة".

حاولت الدراسة التعرف على مقدار المعاناة التي تعيشها المرأة المعيلة والتي تتعلق بوجود



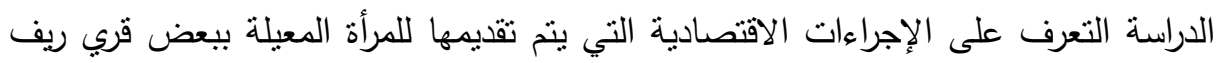

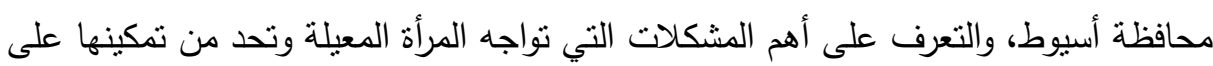
المستوى الاقتصادي والاجتماعي ببعض قري ريف محافظة أسيوط، وقد نم تطبيق الدراسة

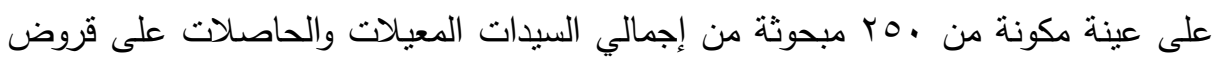

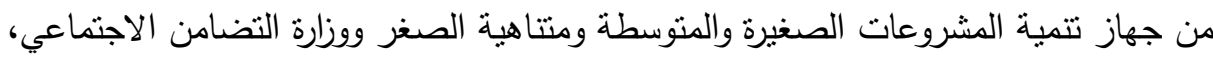
وذلك عبر أسلوب المقابلة الثخصية. وتتلخص أهم نتائج الدراسة في كون أكثر المشروعات

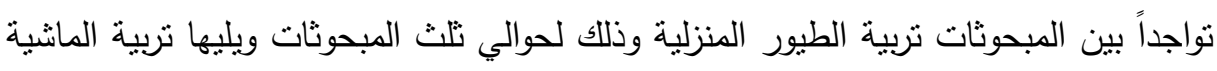

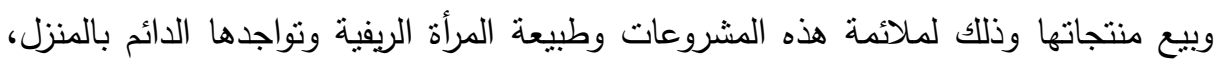
وكذلك سهولة نسويق منتجاتها. كذلك نجد أن ^r٪ من المبحوثات المتعثرات في سداد قيمة

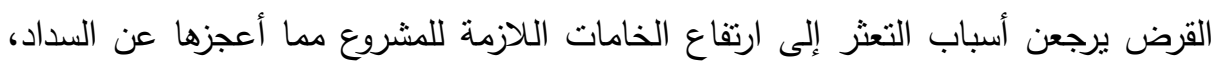

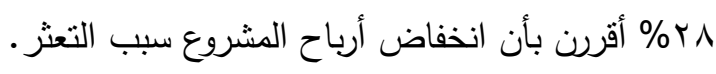



$$
\begin{aligned}
& \text { التزقيم الدولي 0826- ISSN 1110 } \\
& \text { الترقيم الدولي الموحد الإلكتروني 3178-2636-26 }
\end{aligned}
$$


r. دراسة (نارمين إبراهيم العزلي) بعنوان: دراسة إلاثر الإقتصادي للمشروعات الصغيرة على

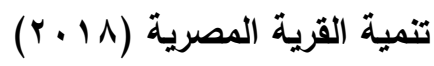

حاولت الدراسة إلقاء الضوء على المشروعات الصغيرة حيث أنها تلعب المشروعات


القومي حيث توفر ملايين من فرص العمل اللثباب.

وتستهدف الدراسة الحالية إلى قياس الأثر الإقتصادي للمشروعات الصغيرة الصنية على تنمية

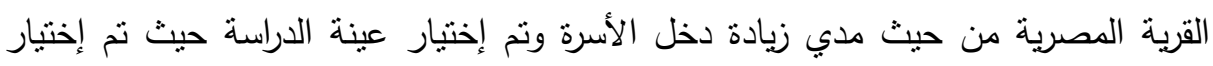
عينة من ثلاث مشروعات من محافظة الجيزة هي مشروع تربية الأسماك مشروع تربية النحل

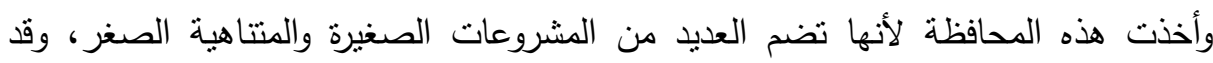

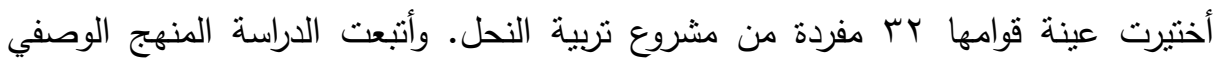

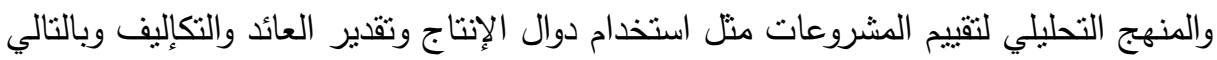
تقدير ربحية هذه المشروعات.

وقد توصلت الدراسة إلي عدد من الننائج من أهمها: أثنارت ننائج مشروع تربية النحل

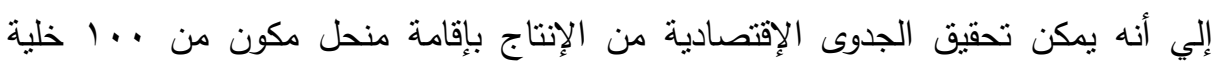



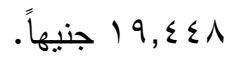
r. دراسة (فادي سعود سماوي)، بعنوان: دور المشاريع الصغيرة في تنمية المرأة الأردنية:

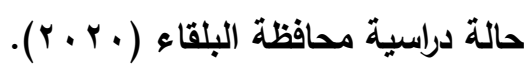

استهلفت الدراسة الكثف عن دور المشروعات الصغيرة في نطوير المرأة بالأردن، كذلك

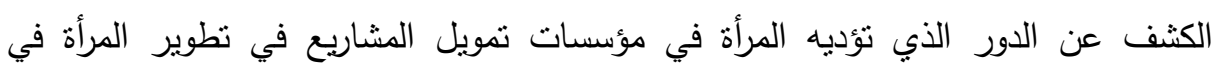

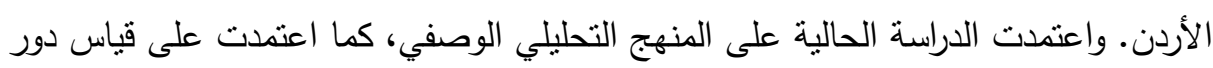

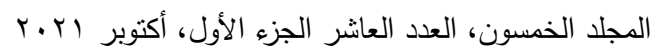

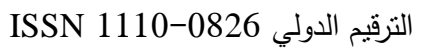

$$
\begin{aligned}
& \text { التزقيم الدولي الموحد الإلكتروني 3178-0826-2636 }
\end{aligned}
$$




\section{مجلة العلوم البيئية \\ كلية الدراسات العليا والبحوث البيئية - جامعة عين شمس البئة \\ حنان كامل فريد وآخرون}

المشروعات الصغيرة في تطوير المرأة، وذلك من خلال بـ فقرة نم توزيعها على أربعة

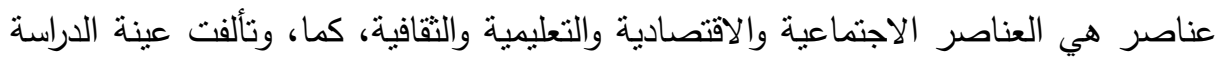
من \& VY امرأة تم اختيارهن بالطريقة العدية المنيسرة.

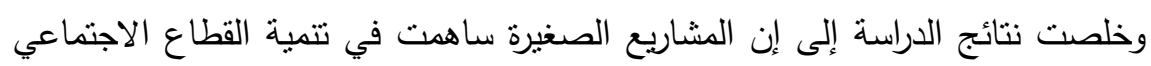
والاقتصادي والنقافي والتعليمي في محافظة البلقاء وذلك بشكل منوسط، في حين أنثارت النتائج إلى الدور الذي تقوم به مؤسسات تمويل المشروعات الصغيرة في تطوير المرأة

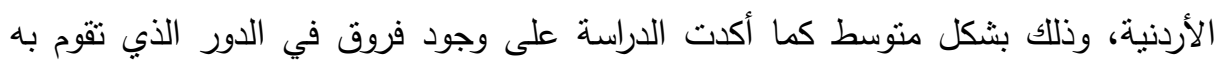
المرأة في المشاريع الصغيرة في تطوير القطاعات الاجتماعية والاقتصادية والتعليمية والتقافية للمرأة الأردنية، وذلك بشكل متوسط، كما أكدت الدراسة وجود فروق في الدور الذي تنؤديه المشروعات الصغيرة في تطوير المرأة الأردنية نرجع لمتغير المستوى التعليمي، وذللك لصالح

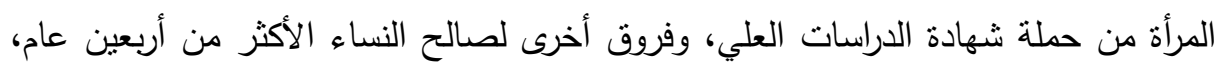

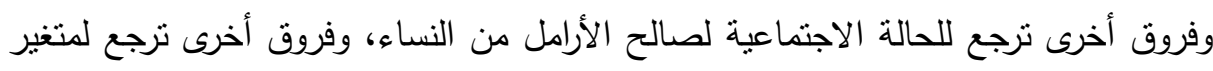

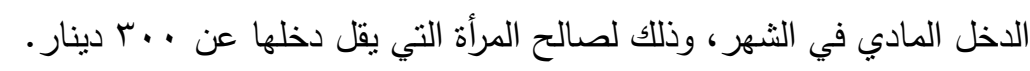



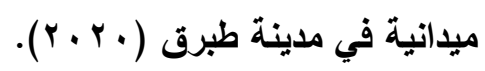

استهدفت الدراسة الكثف عن أبرز المعوقات التي نواجه المشروعات الصغيرة الصيرة في المجتمع في ليييا. وتعتبر الدراسة الحالية من الدراسات الوصفية، واستتدت الدراسة إلى منهج الدئه

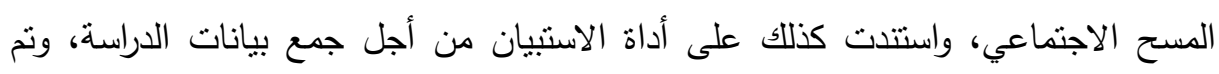
التطبيق على عينة قصدية من ملاك المشروعات الصغيرة في مدينة طبرق.

$$
\begin{aligned}
& \text { المجلد الخمسون، العدد العاثر الجزء الأول، أكتوبر ابr.r. }
\end{aligned}
$$

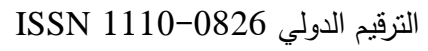

$$
\begin{aligned}
& \text { الترقيم الدولي الموحد الإكتروني 3178-2636 }
\end{aligned}
$$


وخلصت الدراسة إلى إن من أبرز المعوقات التي تواجه المشروعات الصغيرة تتمنل في المعوقات التسويقية، وكذلك المعوقات التمويلية، والمعوقات الإدارية، بالإضافة إلى المعوقات المبند

ه. دراسة (زينهم حسن حسب النبي)، بعنوان: التماس الشباب المصري للمعلومات المرتبطة

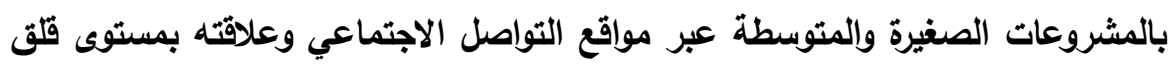

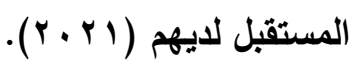

استهدفت الدراسة كثف الرابط بين تعرف الثباب المصري على المعلومات المتصلة

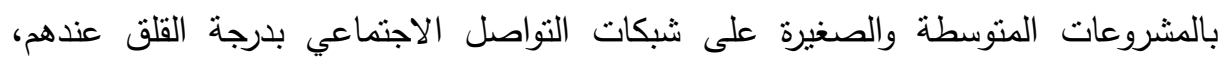

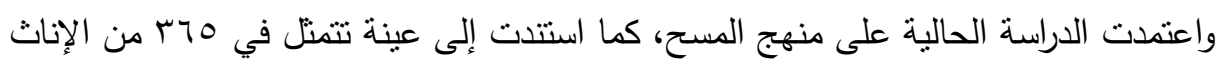

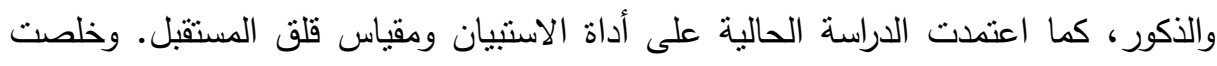
الدراسة إلى كون الثباب المصري يعتمد على شبكات التواصل الاجتماعي من أجل التعرف

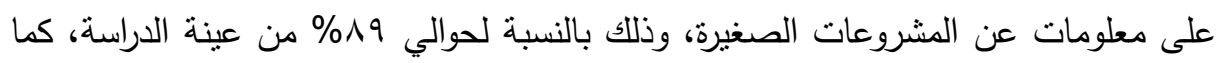

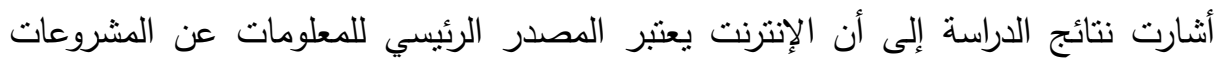

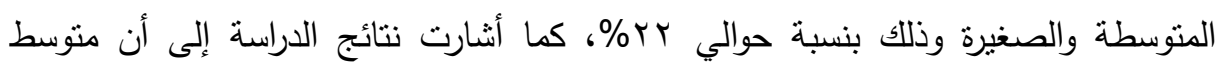

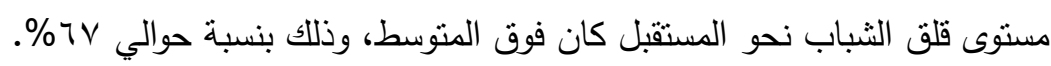

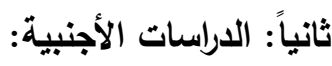
( ) دراسة (Hala El-Said, et.al) بعنوان: المشروعات الصغيرة والمتوسطة في مصر: حقائق جديدة من مجموعة بيانات جديدة (2014)

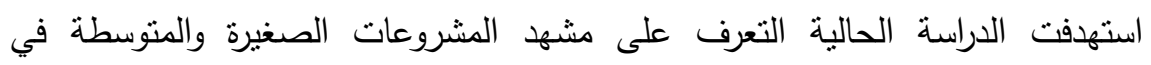
جمهورية مصر العربية، والتعرف على المزيد من الحقائق عن المشروعات الصغيرة والمتوسطة في ظل البيانات الجديدة المنوفرة.

$$
\begin{aligned}
& \text { المجلد الخمسون، العدد العاثر الجزء الأول، أكتوبر ابr.r. } \\
& \text { الترقيم الدولي 0826-1110 } \\
& \text { الترقيم الدولي الموحد الإلكتروني 3178-2636-26 }
\end{aligned}
$$


واعتمدت الدراسة الحالية على المنهج الوصفي التحليلي لمشهد الثركات الصغيرة والمتوسطة في مصر، وذلك بالاعتماد على التعداد الثامل.

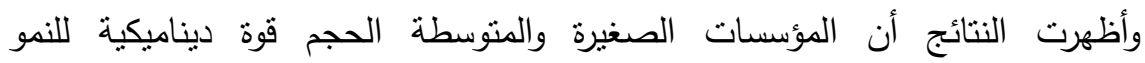
الاقتصادي المستدام وخلق فرص العمل في البلدان النامية بشكل عام، وفي مصر بشكل

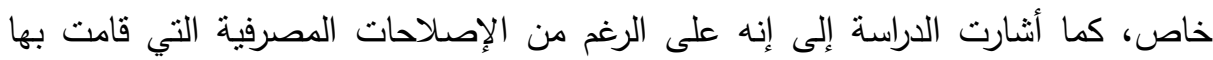

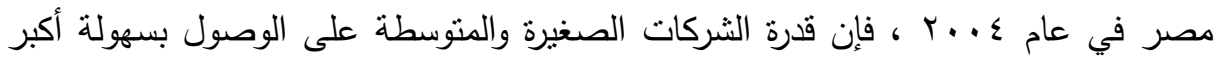

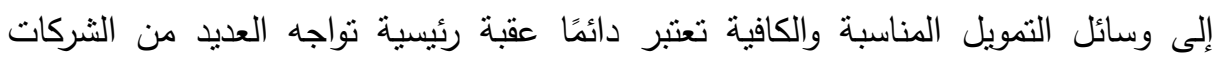
الصغيرة والمتوسطة، وأشارت الدراسة أن مصر قامت بإطلاق مبادرة كجزء لا يتجزأ من

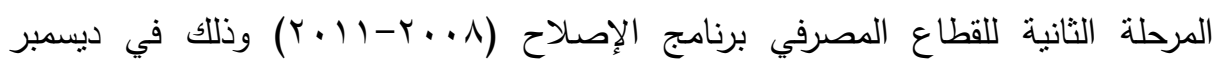
1 . . r، وذلك من أجل أن تكون قادرة على تمديد الخدمات المالية المقدمة لهذه الشريحة وتزيد

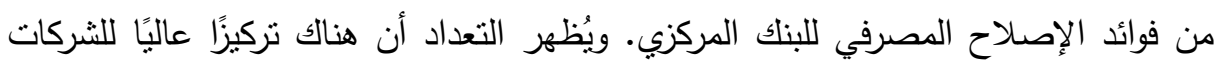
الصغيرة والمتوسطة على مسنويات مختلفة. أولا التوزيع الجغرافي: يؤثز التوزيع الجغرافي على المشروعات الصغيرة والمتوسطة، ويرجع

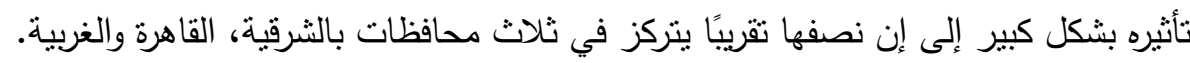

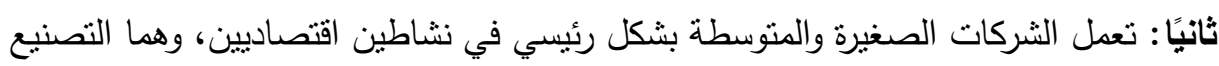

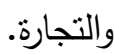
ثالثًا: يقوم عدد قليل جدًا من الثركات بالتصدير، وبيدو أن الخدمات المالية غير مستغلة

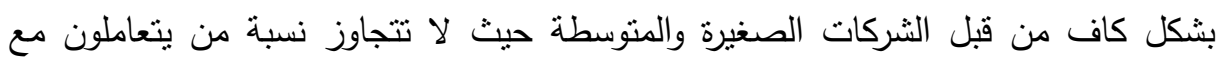
البنوك ويستقيدون من تحسين الوصول إلى التمويل •. في المائة. 
r) دراسة (Rym Ayadi \& et.al,) بغنوان: الشركات الصغيرة والمتوسطة والمتناهية الصغر في كلا من مصر والأردن والمغرب وتونس (2017)


استهدفت الدراسة الحالية التركيز على عدد من الدول منل مصر والأردن والمغرب وتونس، وذللك فيما يتصل بتتمية تلك الدول لقطاعاتها الخاصة مع التركيز على المشاريع المتوسطة

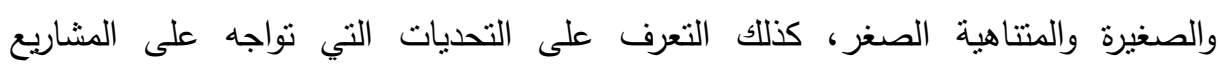
المتوسطة والصغيرة والمتتاهية الصغر في تلك الدول.

وخلصت الدراسة الحالية إلى إن استمرار ارتفاع معدلات البطالة يشكل تحديا لصانعي السياسات في تقليص دور الدولة في خلق فرص العمل، كذلك نقص الفرص الاقتصادية



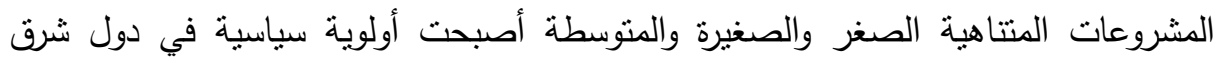
وجنوب البحر المتوسط التي تعاني من البطالة، في البلدان الأربعة قيد الدراسة في هذه وله

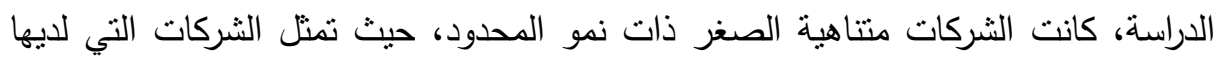
أقل من أربعة أو عشرة موظفين

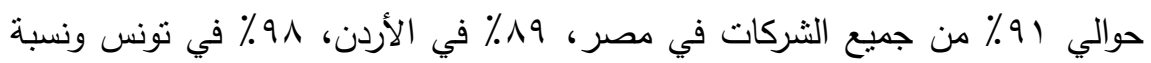

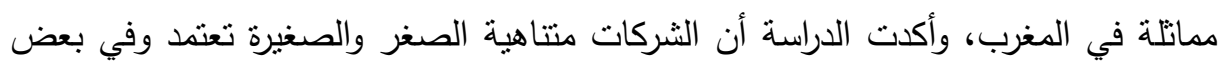

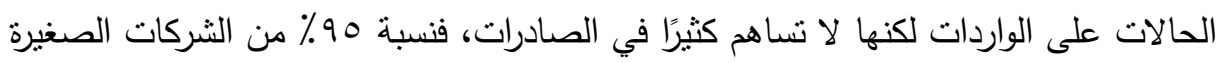
و r^ \% من الثركات المتوسطة لبس لديها أي نشاط تصديري في مصر ، بينما تعتمد حوالي

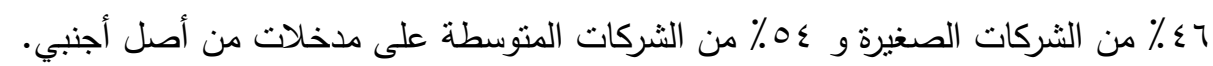

$$
\begin{aligned}
& \text { المجلد الخمسون، العدد العاشر الجزء الأول، أكتوبر ب.r.r. }
\end{aligned}
$$

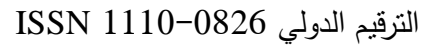

$$
\begin{aligned}
& \text { الترقيم الدولي الموحد الإلكتروني 3178-2636-26 }
\end{aligned}
$$




$$
\begin{aligned}
& \text { مجلة العلوم البيئية } \\
& \text { كلية الدراسات العليا والبحوث البيئية - جامعة عين شس البئ } \\
& \text { حنان كامل فريد وآخرون }
\end{aligned}
$$

r) دراسة (Jasika Alam Jitu) بعنوان: التمكين الاقتصادي للمرأة والثركات الصغيرة

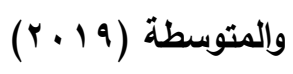

استهدفت الدراسة الحالية تقييم فعالية الثركات الصغيرة والمتوسطة على حياة النساء المعوزات في بنغلاديش، كذللك تقييم إمكانية الثركات الصغيرة والمتوسطة تحسين حياة النساء

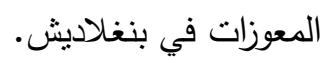

وخلصت الدراسة الحالية إلى عدد من النتائج ومن بينها أن الثركات الصغيرة والمنوسطة تقدم قدرا كبيرا من الدعم الذي تحتاجه النساء المعوزات، وذلك من أجل تحقيق التمكين الاقتصادي، كما أثنارت نتائج الدراسة إلى اعتماد المشاريع الصغيرة والمتوسطة التي تملكها المرأة إلى حد كبير على عدد من القضايا الاجنماعية والسياسية والبيئية المرتبطة بها، كما أكدت نتائج الدراسة على إن عدم المساواة الموجودة في بنغلاديش واحدة من أهم القضايا من عن الهن حيث التأثير على الثركات الصغيرة والمتوسطة، وبالتالي على الاقتصاد وتمكين المرأة

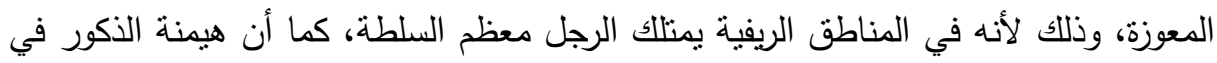

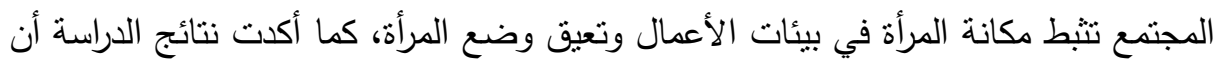
عنصر توافر موارد الرزق إلى جانب دعم الأسري كانا لهمها دور مهم في تمكين المرأة

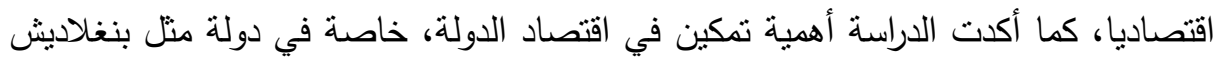

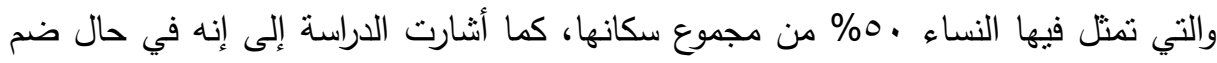

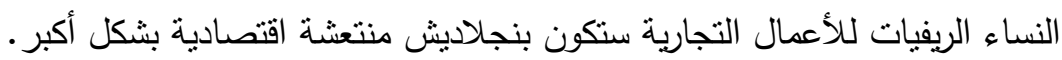

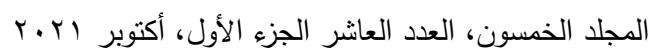

$$
\begin{aligned}
& \text { التزقيم الدولي 0826- ISSN 1110 } \\
& \text { التزقيم الدولي الموحد الإلكتروني 3178-2636 }
\end{aligned}
$$


؛ ) دراسة (G. I. Mansour \& et.a) بعنوان: دور المؤسسات الصغيرة والمتوسطة في الاقتصاد والتنمية، حالة مصر (2019). استهدفت الدراسة الحالية التعرف على دور المؤسسات الصغيرة والمتوسطة في الاقتصاد والتتمية في دولة مصر، كذلك التعرف على أهم المشكلات والمعوقات التي نواجه هذه لهونه المشروعات في جمهورية مصر العربية.

وأظهرت النتائج أن مصر بها م, r مليون من المشاريع الصغيرة والمنوسطة والمتتاهية



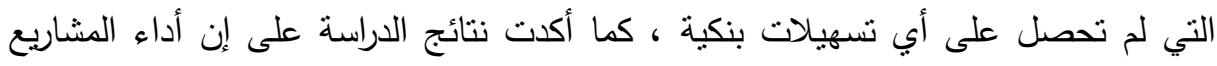
الصغيرة والمتوسطة كان ضعيف جدا من حيث التصدير إلى الخارج، وأثنارت الدراسة أنه إنه

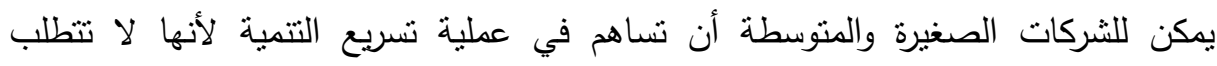



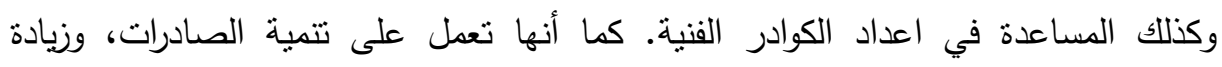

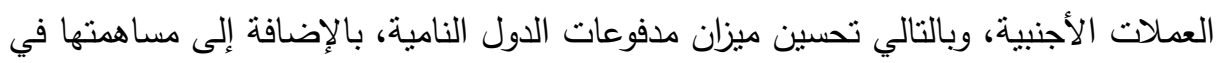

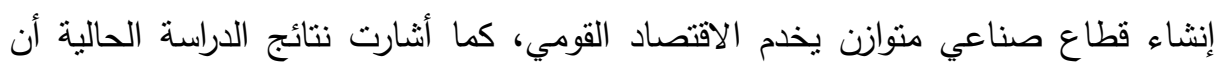

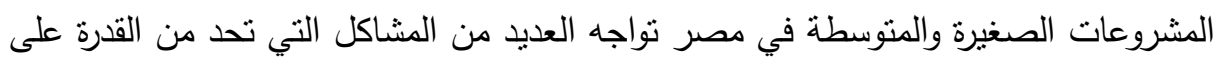

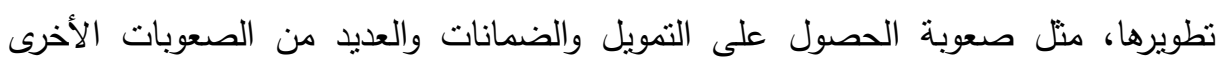
المتعلقة ببيئة الأعمال غير الملائمة والقوانين، بالإضافة إلى اللوائح وضعف ولئ البنية التحتية

$$
\begin{aligned}
& \text { المجلد الخمسون، العدد العاشر الجزء الأول، أكتوبر ب.r.r. }
\end{aligned}
$$

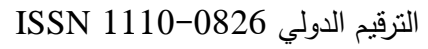

$$
\begin{aligned}
& \text { الترقيم الدولي الموحد الإلكتروني 3178-2636-26 }
\end{aligned}
$$




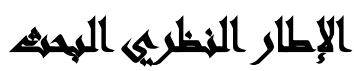

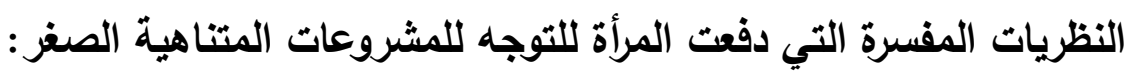

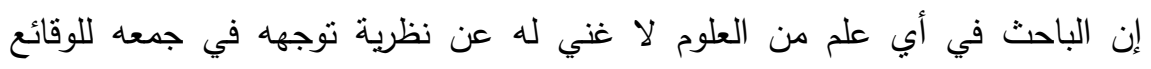

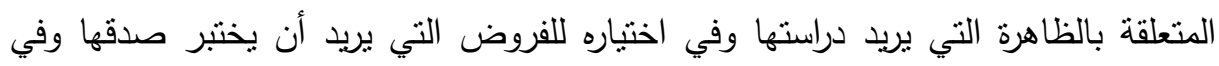

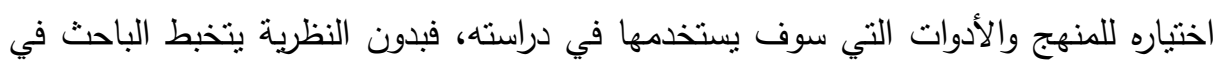

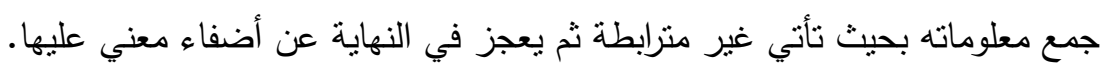



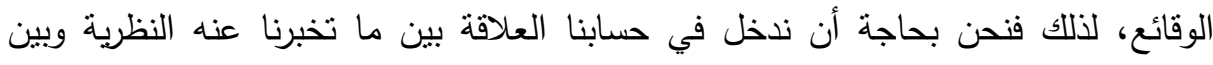

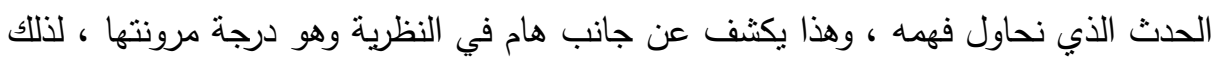

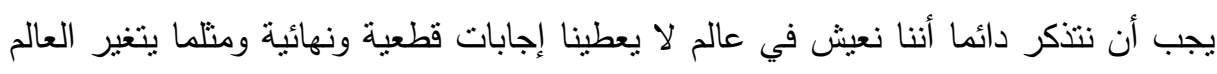

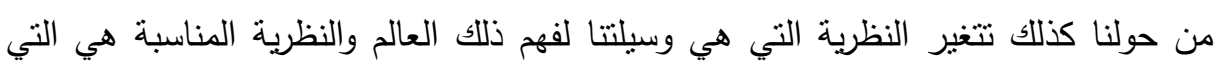

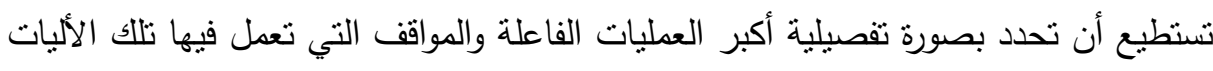

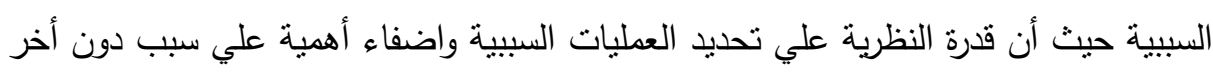

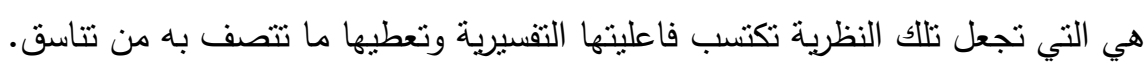

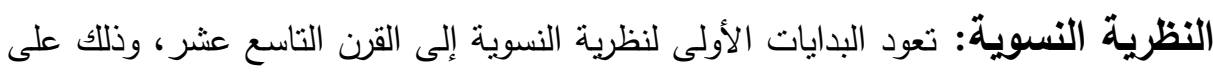

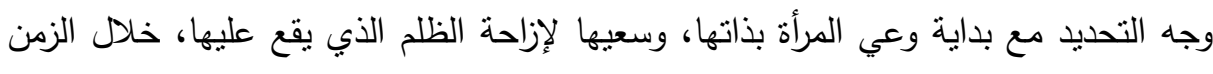



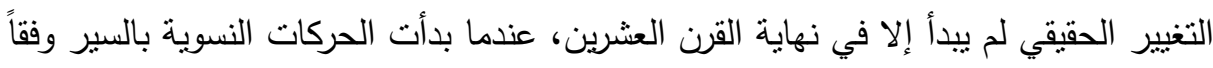

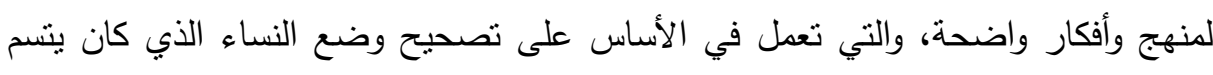



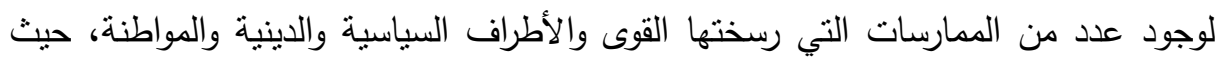
94

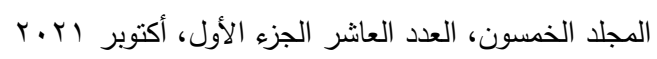

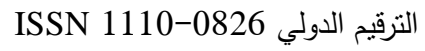

$$
\begin{aligned}
& \text { التزقيم الدولي الموحد الإلكتروني 026-3178-2636 }
\end{aligned}
$$


واجهت المرأة كم هائل من الضغوطات التي جعلتها بعيدة لفترة من الزمان (عثمان واصل،

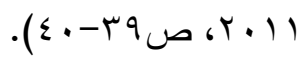

ويقوم تعريف النسوية على الاعتقاد بأن المرأة لا تعمل على قدم المساواة إلا لوكنها امرأة

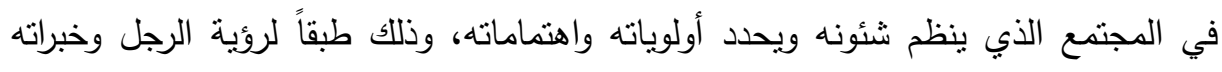

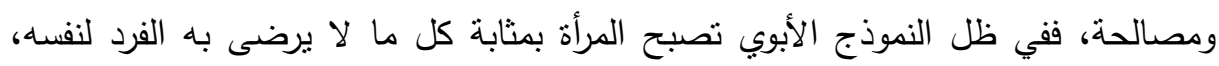
فالرجال يمتازون بالقوة والمرأة تمناز بالضعف، كذللك يرون أن الرجل يتصف بالصفي بالعقلانية، فيما

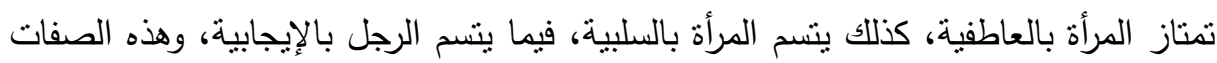

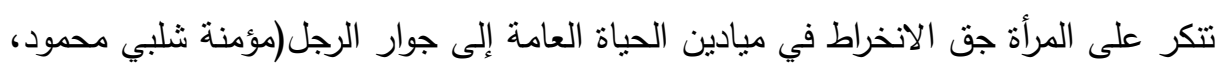

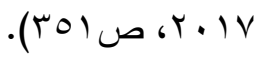

وقد ظهر مفهوم النسوية في الأساس على يد الفرنسية "هوبرتين أوكلير" وذللك عام

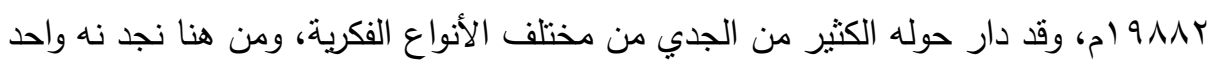


والنسوية تعبر كذلك عن مفهوم يحاول أن يشرح ويحلل ظروف النساء، فهي الطريقة

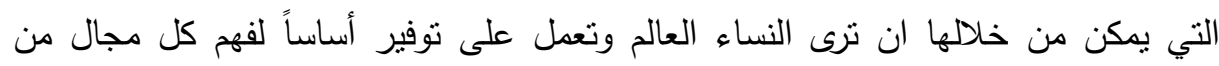

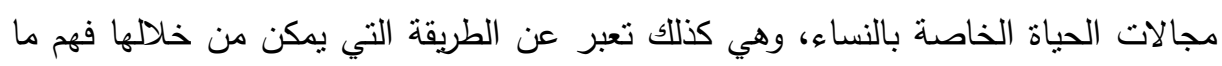
يحدث حولنا أو داخلنا. وتقترح هذه النظرية استراتيجيات تعمل على تحسين ظروف النقاء النساء

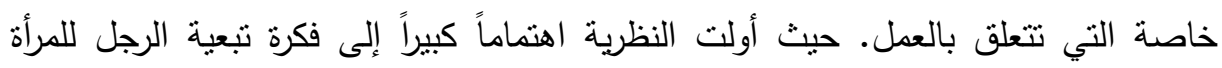



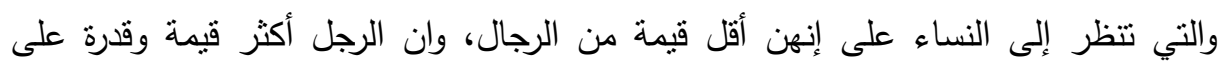

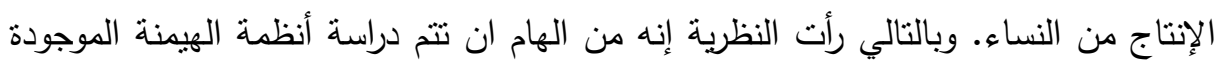

$$
\begin{aligned}
& \text { المجلد الخمسون، العدد العانشر الجزء الأول، أكتوبر ابr.r }
\end{aligned}
$$

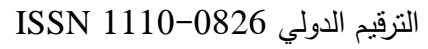

$$
\begin{aligned}
& \text { الترقيم الدولي الموحد الإلكتروني 3178-2636-26 }
\end{aligned}
$$


بالمجتمع سواء التي تقوم على هيمنة الجنس او العرق او العمر أو القومية وغيرها من الأمور

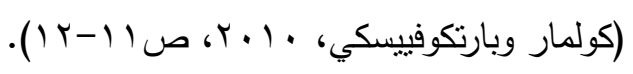

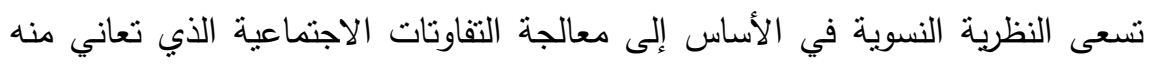

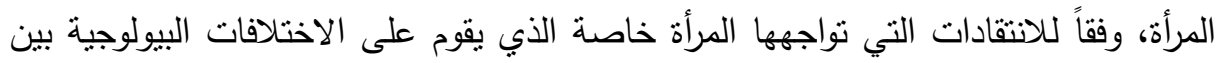

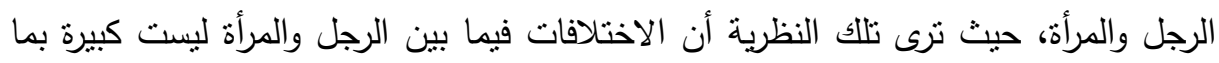


بحق المرأة إذا ما قارنا ما تحصل عليه بما يحصل عليه الرجال في المجتمع. وتقوم هذه

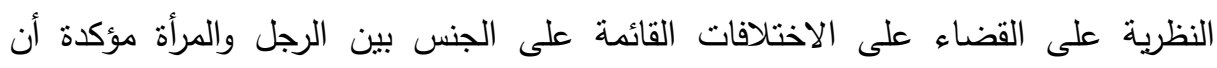

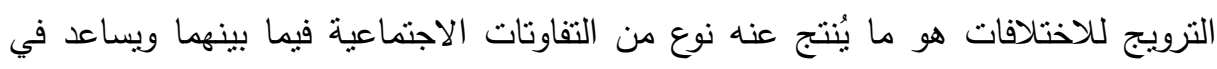

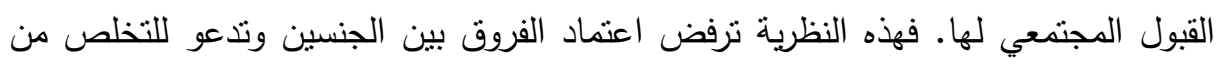

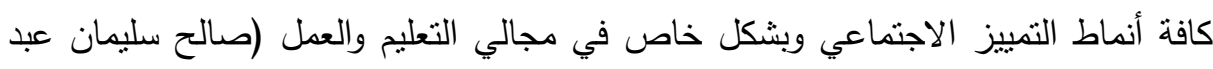

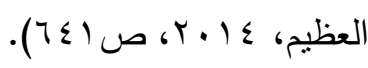

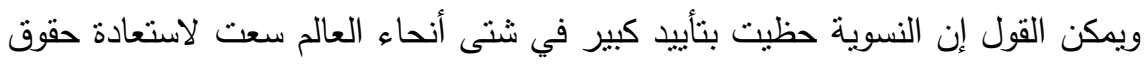

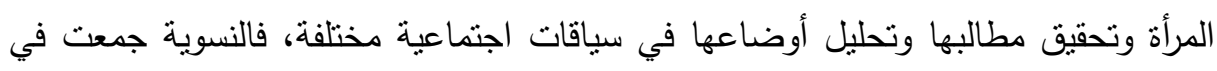

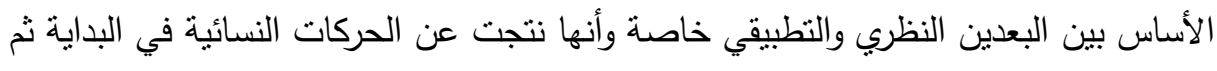

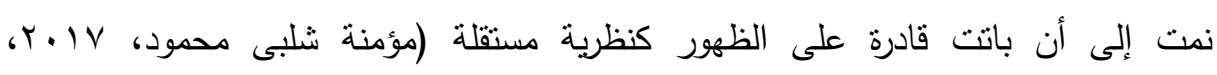



وقد أثنار البعض إلى أن نظرية النسوية قد نجت في القضاء على العديد من العقبات

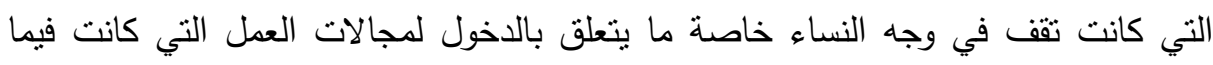

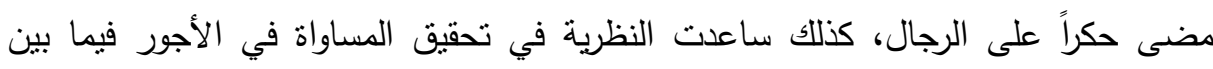



$$
\begin{aligned}
& \text { المجلد الخمسون، العدد العاثر الجزء الأول، أكتوبر ابr.r. } \\
& \text { التزقيم الدولي 0826- ISSN 1110 } \\
& \text { الترقيم الدولي الموحد الإلكتروني 3178-2636-26 التربي }
\end{aligned}
$$


والمساواة في الأجر ؛ حيث رأت النظرية إنه من غير المعقول أن يتم تبرير الفروق بين الرجل

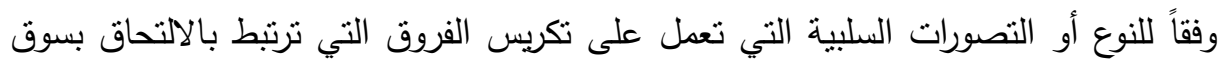

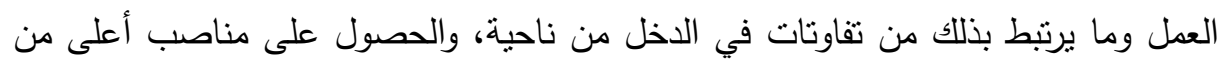

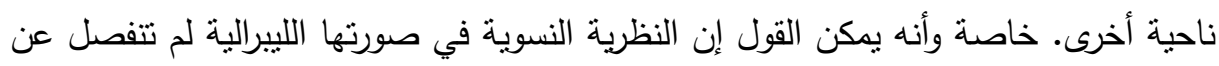

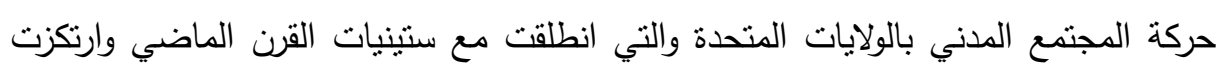

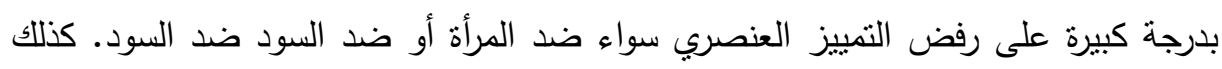



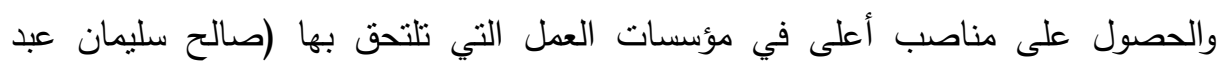

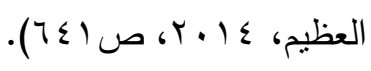

وما يجب التأكيد عليه في ضوء النظرية النسوية هو أنها لا نعمل على تمكين المرأة

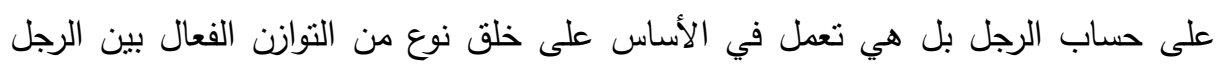

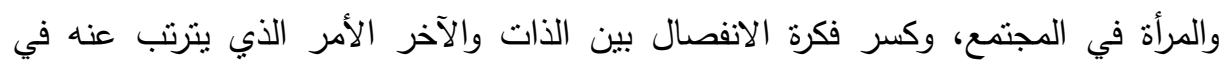



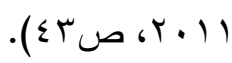
ونظرا لأننا نقوم هنا بتتاول التنغيرات الإجتماعية والبيئية التي دفعت المرأة للتوجه نحو

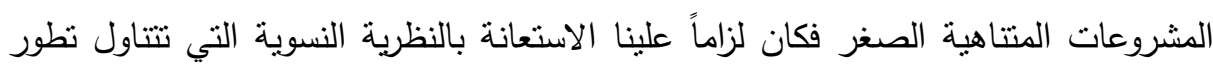

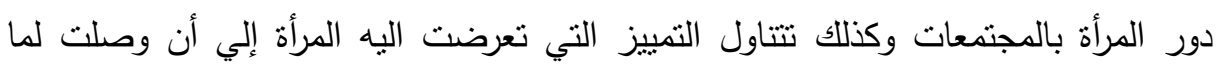

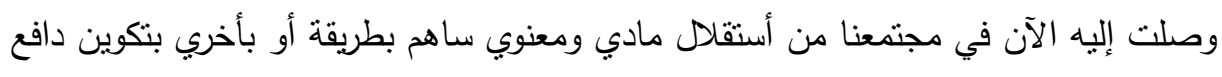

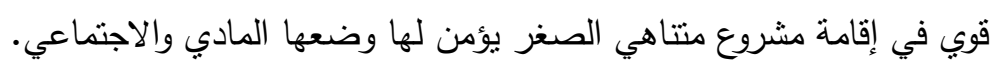

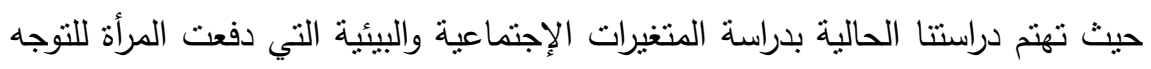

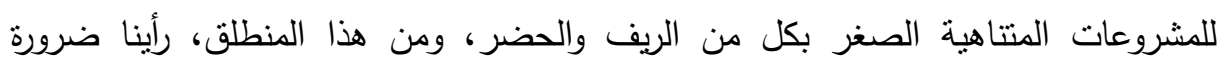

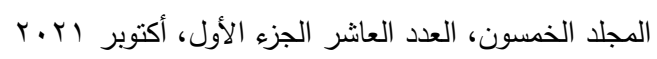

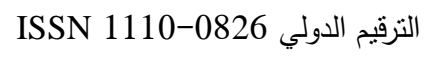

$$
\begin{aligned}
& \text { التزقيم الدولي الموحد الإلكتروني 3178-0826-2636 }
\end{aligned}
$$


الاستفادة من النظرية النسوية لكونها تقدم تقسيرا لدور المرأة بالمجتمع محل الدراسة وكذللك

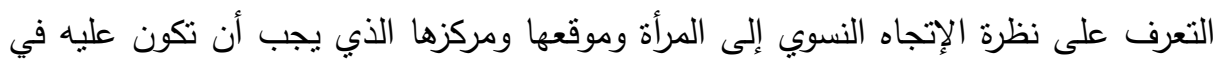
أي مجتمع من المجتمعات.

النظرية البنائية الوظيفية: برز الاتجاه الوظيفي في تحليل الظواهر الاجتماعية لاى علماء

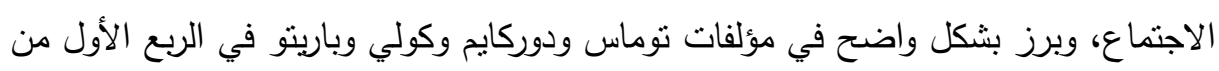

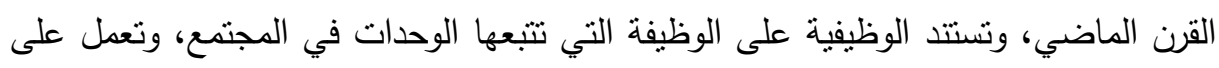

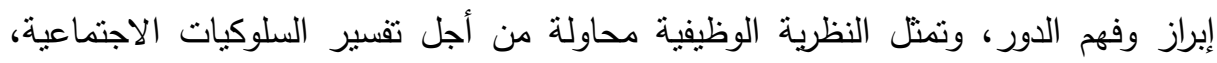
وذلك من خلال الرجوع إلى تأثثرات النتائج التي يقوم ذلك السلوك بتحقيقها، حيث يقول يقول باريتو أن المجتمع يعبر عن نسق منوازن يقوم بتحقيق شرط تتعاون فيه المعايير والأفكار التقافية

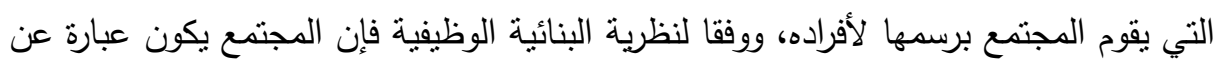

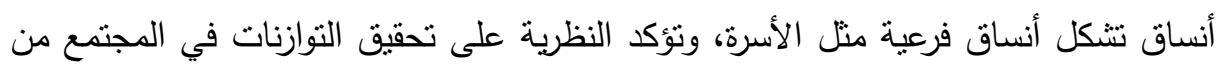

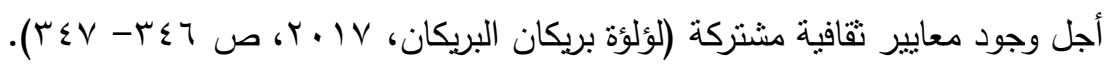

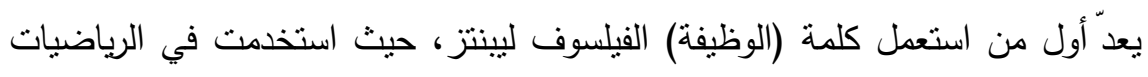
لبيان العلاقة بين متغيرين. ولكن اختلفت الآراء حول البدايات الأولى للنظرية، حيث أنثار

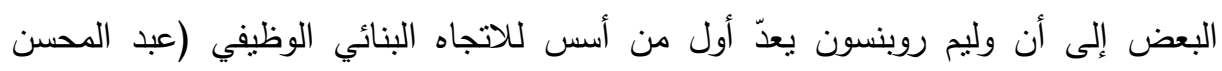

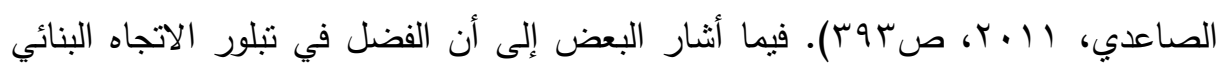

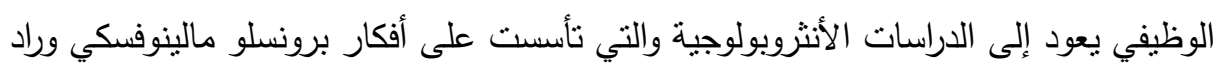

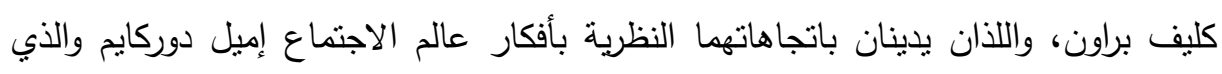

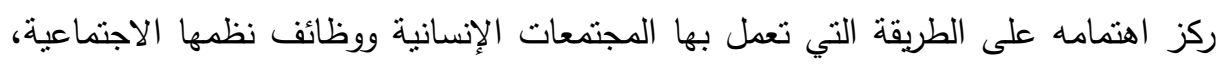

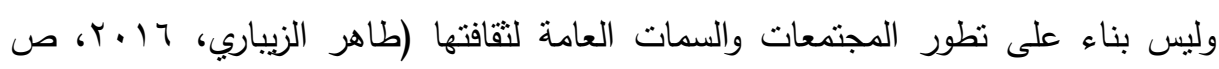

$$
\begin{aligned}
& \text { المجلد الخمسون، العدد العاثر الجزء الأول، أكتوبر ابr.r. }
\end{aligned}
$$

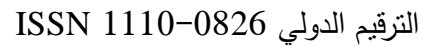

$$
\begin{aligned}
& \text { الترقيم الدولي الموحد الإكتروني 3178-2636 }
\end{aligned}
$$


بينما يرى آخرون أن الأصول النظرية لهذا المنظور تمند إلى النموذج العلمي والوضعي،

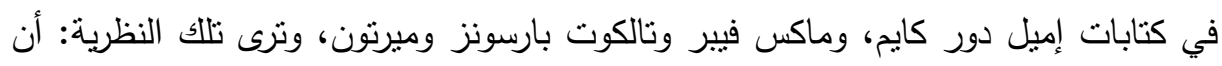
الظاهرة الاجتماعية تتشأ نتيجة للتفاعل داخل الأبنية الاجتماعية، كما تتظر للتنظيم على بلى أنه رمز للتفاعل الاجتماعي أو نتاج للتبادل الاجتماعي. ويؤكد الاتجاه الوظيفي في دراسة وتفسير

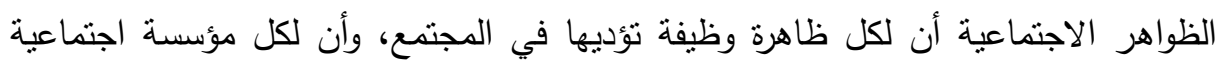

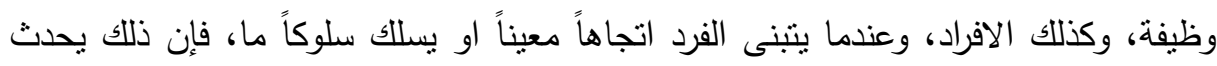

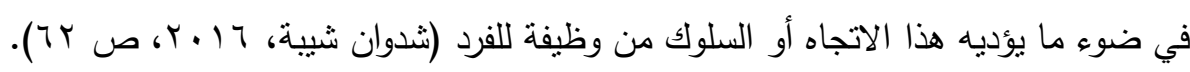

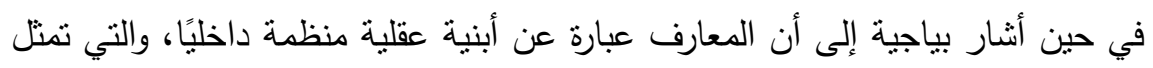



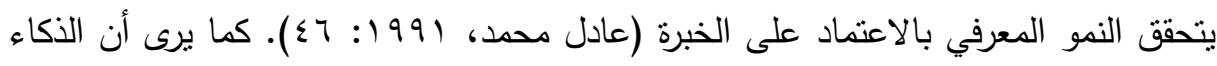
هو الأفعال التي تبرهن على قدرتتا على التكيّف في المواقف الجديدة؛ حيث ينبثق فهمنا

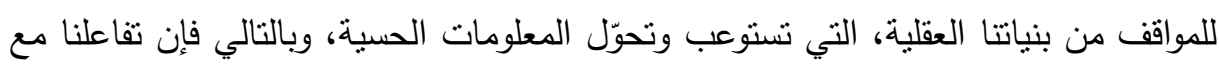



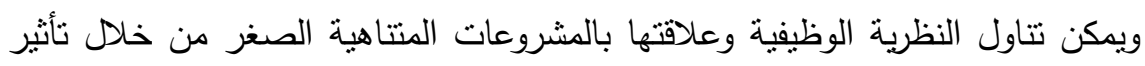
المشروعات المتتاهية الصغر بظاهرة الترتيب الطبقي داخل المجتمع. حيث تستتد هذه النظرية

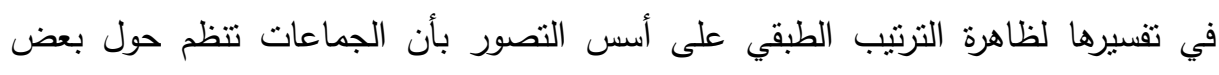

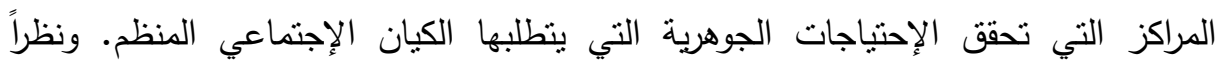


بصورة تدريجية منسلسلة تبعا لأهميتها وقيمتها. ولذلك يوجد داخل المجتمع سلسلة أو نرسيب إجتماعي واسع يقوم على أساس القيم والحاجات التي يتوقف عليها بقاء المجتمع ذاته.

$$
\begin{aligned}
& \text { المجلد الخمسون، العدد العاثر الجزء الأول، أكتوبر ابr.r. } \\
& \text { الترقيم الدولي 0826-1110 } \\
& \text { الترقيم الدولي الموحد الإكتروني 3178-2636 }
\end{aligned}
$$


الوظيفية وتوجه المرأة للمشروعات المتتاهية الصغر في كل من الريف والحضر : هذا باختصار مفهوم النظرية الوظيفية البنائية وقد نم اختيار هذه النظرية لتوجيه البحت البهن لأنها أولاً نظرية إجتماعية بحتة ودراسة المتغيرات الإجتماعية والبيئية التي دفعت المرأة للتوجه

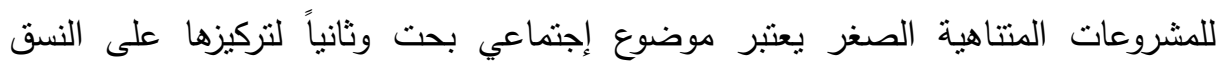
والنظام والوظيفة التي هي عناصر أساسية في دراسة هذا الموضوع. من هنا تفسر النظرية "البنائية الوظيفية" التغير الإجتماعي بتغير جزئي يطرأ على أحد



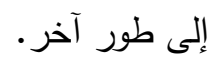

ومن هنا يمكن تفسير عمل المرأة وفقا للنظرية البنائية الوظيفية أن المرأة في مجتمعنا المصري يدفعها إلي النوجه للمشروعات المتتاهية الصغر مجموعة من المتغيرات الإجتماعية

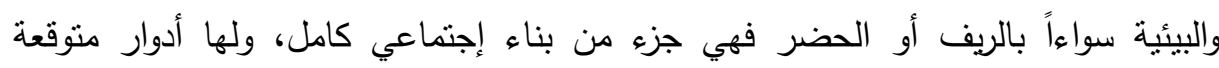

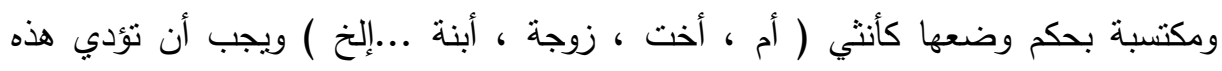

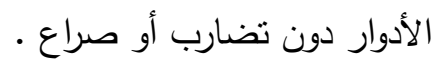
وانطلاقاً من مبدأ التساند والترابط الوظيفي بين الظواهر، فإن دان عمل المرأة في مجال المشروعات المتتاهية الصغر مرتبط بمجموعة من المتغيرات الإجتماعية والبيئية والتي سنقوم بدراستها في هذه الرسالة.

ويمكن دراسة الدوافع الأساسية لعمل المرأة بالمشروعات المتتاهية الصغر الي دوافع

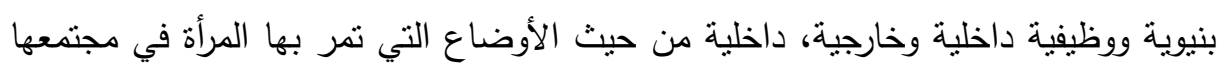

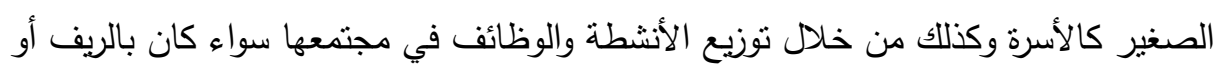

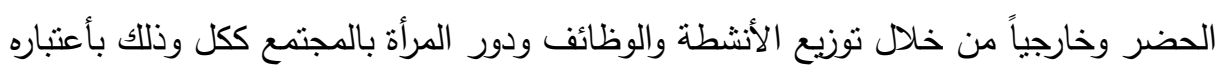
أحد الركائز الهامة في بناء المجنمع. 100

$$
\begin{aligned}
& \text { المجلد الخمسون، العدد العاثر الجزء الأول، أكتوبر ابr.r. } \\
& \text { التزقيم الدولي 0826- ISSN 1110 } \\
& \text { الترقيم الدولي الموحد الإلكتروني 3178-2636-26 التربي }
\end{aligned}
$$


ونلاحظ أن ظاهرة نزول المرأة الي سوق العمل وإقبالها علي المشروعات المتتاهية الصغر سواء في الريف أو الحضر من المواضيع الأساسية في العلاقات الإقتصادية سواء في لئي المجتمعات الحضرية أو في المجتمعات الريفية.

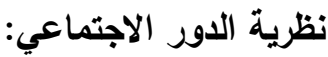

اعتبر المفكرون السياسيون مثل جوزيف مورينو وجورج ميد نظرية الدور الاجتماعي أنها ترتبط بالطابع الوظيفي والسلوكي الذي يقوم به الأفراد بغرض حل مشاكلها، ومن منّ ثمّ فقد أثناروا

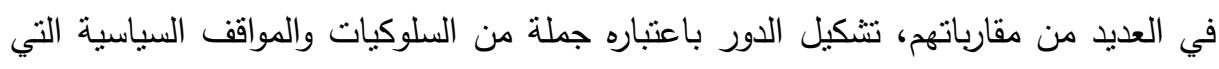
تنتباها النخب السياسية، وكنتيجة لاستخدام نظرية الدور، فقد بات بالإمكان توقع أدوار الأفراد

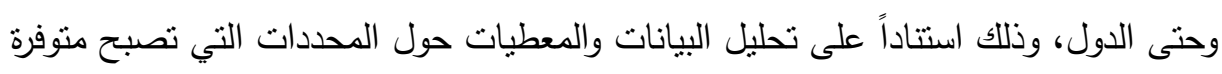
لايها، والتي ثُدعى مصادر الدور، وهذا يقود إلى توصيف الدور وتئى وتحديده. (بشير النجاب،

ويتم تفسير الدور باعتباره وظيفة أو موقع أو عمل يقوم به بعض أفراد المجتمع، ويفرص



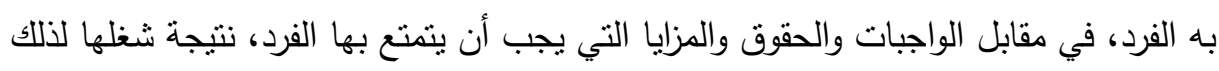
الدور بحكم موقع الفرد، ويؤدي الفرد في حياته الاجتماعية أدواراً ينوقعها منه المجتمع نظراً

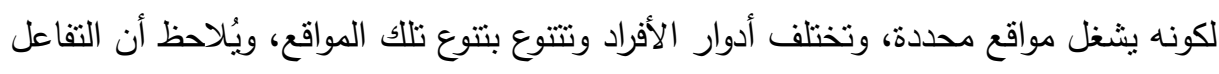
بين تلك الأدوار يكون ما بطلق عليه البناء الاجتماعي، والذي يمنل مجموعة أنظمة اجتماعية تتفاعل وتتداخل في تحديد وتتكيل أنماط السلوك، وتعمل على نتظيم الحاجات الإنسانية وفقاً

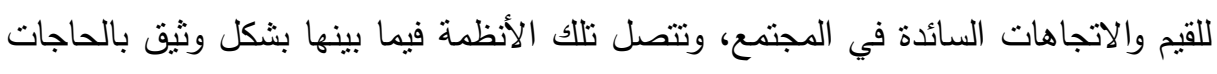
الإنسانية وفقاً للقيم والاتجاهات السائدة في المجتمع، وتتصل نلاتك الأنظمة فيما بينها بشكل وثثق وظيفيا، بهدف تكامل البناء الاجتماعي والعمل على استمراره، ومن ثُّ فإن هناك

$$
\begin{aligned}
& \text { المجلد الخمسون، العدد العاثر الجزء الأول، أكتوبر ابr.r. } \\
& \text { الترقيم الدولي 0826- ISSN 1110 } \\
& \text { الترقيم الدولي الموحد الإلكتروني 3178-2636-26 التربي }
\end{aligned}
$$


معطيات اجتماعية للدور، تتمثل في البناء الاجتماعي من الوحدات التي تتكل المواقع

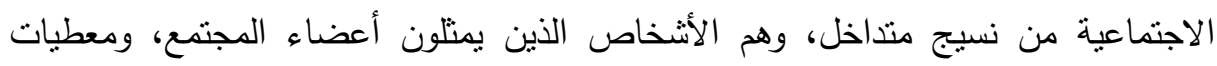
أنثروبولوجية للدور ، والتي تتضمن الواجبات والحدود المقترنة بكل موقع على حدة، والتي تعتبر

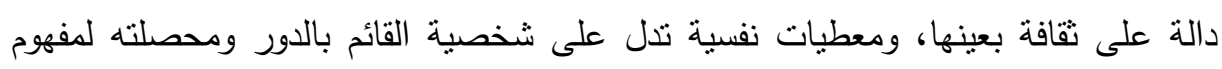

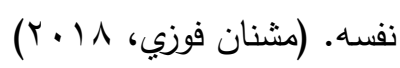

وقد بدأت نظرية الدور تؤثر في الوقت الراهن على ممارسة خدمة الفرد، كما أخذت الته

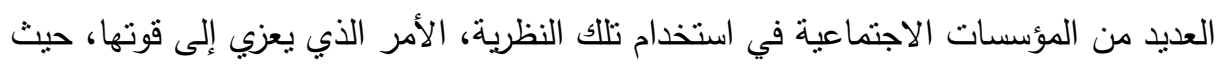
أنها تتصف بالثراء في مكوناتها النظرية ومفاهيمها، وقدرتها على تقديم طريقة مناسبة لتحليل ودراية السلوك الاجتماعي في صورة السوية، وذلك من حيث: - المراكز الاجتماعية والأدوار وتتظيماتها وخصائصها. - - التوافق الاجتماعي والعمليات الخاص بهن. - - التشئة الاجتماعية والمشاكل الخاص بها.

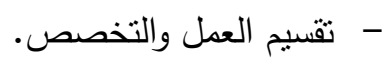

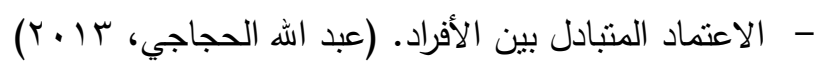

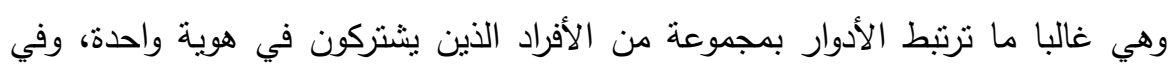
الغالب يكون الافراد على وعي بالأدوار التي يقوموا بها ومدركين تماما لها.

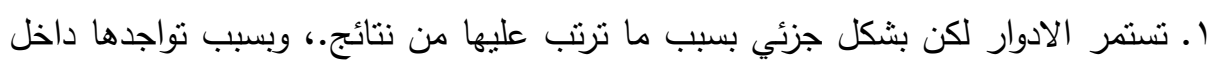
نظم اجنماعي اوسع. r. يجب أن يتأهل الافراد ويتعلموا حول الادوار التي يعهد إليهح بها وتكون منوطة بهر.

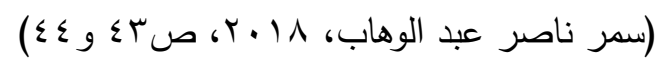

$$
\begin{aligned}
& \text { المجلد الخمسون، العدد العاثر الجزء الأول، أكتوبر ابr.r. }
\end{aligned}
$$

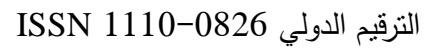

$$
\begin{aligned}
& \text { الترقيم الدولي الموحد الإلكتروني 3178-2636-26 التربي }
\end{aligned}
$$


نظرية الدور الاجتماعي وتوجه المرأة للمشروعات المتتاهية الصغر في كل من الريف والحضر: إن من أهم مظاهر التغير في البنية الاجتماعية الذي طال المجتمعات العربية حديثاً هو

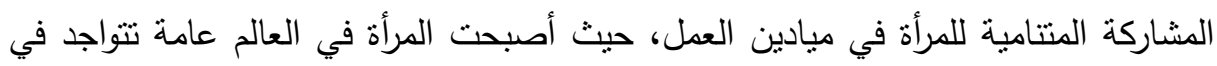
معظم القطاعات إلا أن خروج المرأة إلى العمل تمخض عنده آثار عديدة منها ما هو إيجابي

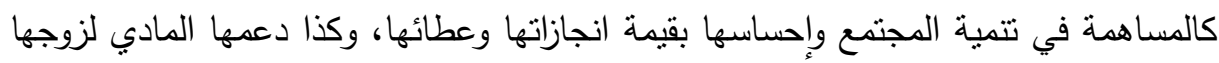



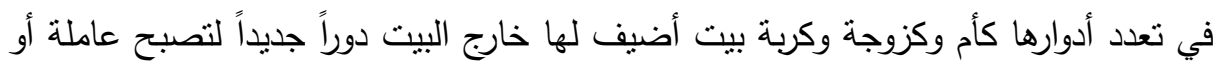



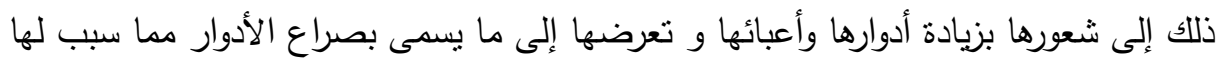
بعض الصعوبات النفسية والإجتماعية والمهنية والدراسة الحالية تبحث المتغيرات الإجتماعية والبيئية التي دفعت المرأة الي التوجه الي المشروعات المتتاهية الصغر حيث واتئه تختلف هذه الأدوار وفقاً لهذه الجماعات لأنها تستمد أهميتها ومصادرها وتحدد من خلال هذه الأنظمة وألا نساق المنتكة في القيم والمعايير والديانة السائدة في المجتمع كما نتأثر بالبيئة التي تميز وتكيف أسلوب حياة هذه الجماعة وبالتالي تحدد سلوك الأفراد و واكتسابهم وتعليمهم لأدوارهم

ونشاطاتهم وممارستهم اليومية وفقا لاحتياجاتهم البيولوجية والنفسية والعائلية والإجتماعية .

\section{إلجراءائه المهمث}

منهج البحث: اعتمدت الدراسة الحالية على المنهج الوصفي التحليلي، والذي تم التركيز عليه بشكل ملحوظ في القرن العشرين، حيث ارتبط ذلك الأسلوب منذ بدايته بدراسة المشكلات التي تتعلق بالمجالات الإنسانية كالبحوث السلوكية، وذلك لعدم قدرة الباحث على إجراء

$$
\begin{aligned}
& \text { المجلد الخمسون، العدد العاشر الجزء الأول، أكتوبر ب.r.r. }
\end{aligned}
$$

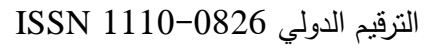

$$
\begin{aligned}
& \text { الترقيم الدولي الموحد الإلكتروني 3178-2636-26 }
\end{aligned}
$$




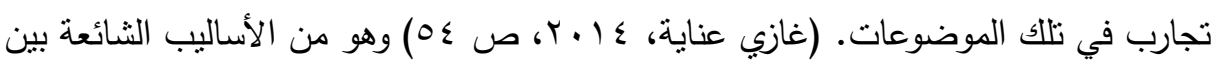

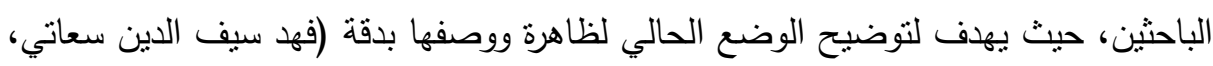

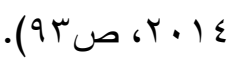

ومن هنا يعدّ هذا المنهج هو الأنسب لموضوع الدراسة الحالي، وذلك من أجل وصف

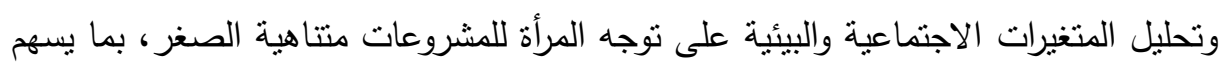
في فهم توجهات المرأة وطبيعة الأنشطة التي تقوم بها في المجتمع الحضري والريفي.

\section{مجتمع وعينة البحث:}

تمثل مجتمع البحث الحالي في محافظتي القاهرة، وسوهاج، بينما تكونت العينة من

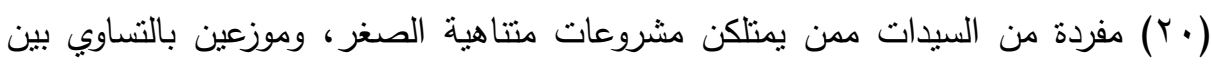

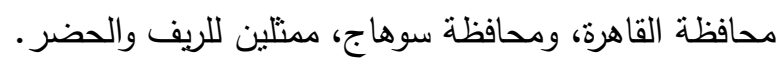
أدوات جمع البيانات: بعد الأطلاع علي عدد من الدراسات والأبحاث ذات العلاقة بالموضوع و باعتبار أن تلاك الدراسة تقع ضمن الدراسات الوصفية ، فإن الباحثة أعتبرت أن الآداة الملائمة لجمع بيانات الدراسة الراهنة هي دراسة الحالة والتي يستخدم فيها دليل المقابلة

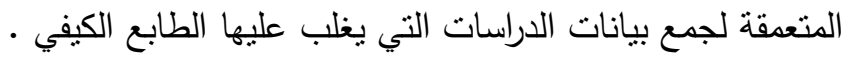
وضم هذا الدليل r محاور كل محور يتكون من • ا أسئلة تحاول الباحثة من خلاله

$$
\text { الإجابة علي كل التساؤلات التي يسعي البحث للإجابة عليها. }
$$

وقد أعطي الدليل للباحث والحالة معاً قدرأمن الاستفاضة في شرح وتوصيل المعلومة

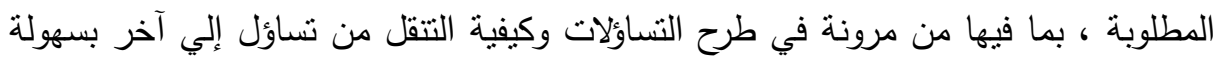

$$
\begin{aligned}
& \text { المجلد الخمسون، العدد العاثر الجزء الأول، أكتوبر ابr.r. } \\
& \text { التزقيم الدولي 0826- ISSN 1110 } \\
& \text { التزقيم الدولي الموحد الإلكتروني 3178-2636-26 }
\end{aligned}
$$


حدود البحث:

الحدود الزمنية: يمتذ النطاق الزمني للاراسة منذ من مارس 1^ بـ وحتى نهاية ديسمبر

. r. r.

الحدود المكانية: محافظة سوهاج - محافظة القاهرة.

الصدق والثبات

صدق وثبات الآداة :

صدق الآداة : قامت الباحثة في إطار مراعاة صدق الآداة بعرض الإستبيان علي عدد من



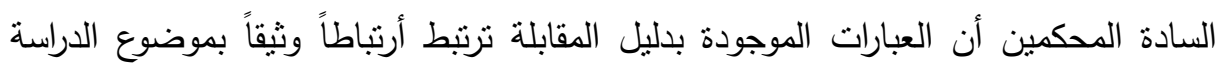

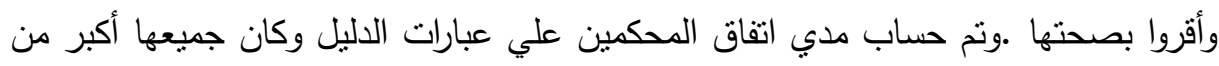

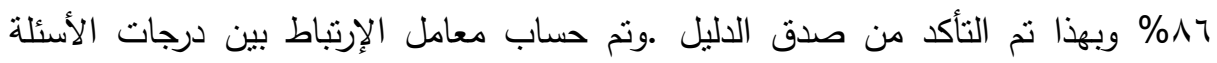

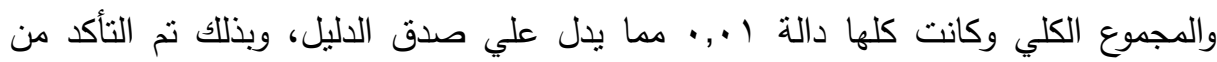

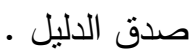



اختبار الثبات: يستخدم هذ المقياس للتأكد من مدى إمكانية الاعتماد على استمارة المقابلة للحصول على بينات تتسم بالثبات. ونم تطبيق ثبات المحتوى، وكذلك ثبات معامل ألفا

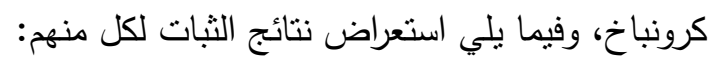
r. 1 ثبات المحتوى: للتأكد من ثنات الدليل قامت الباحثة بإجراء دراسة تجريبية على عينة لها نفس خصائص العينة الأصلية بواقع • (\% من العينة الإجمالية والتي بلغت (دليلين مقابلة )، وبعد إجابة المبحوثتان عليها، تم تعديل صياغة ثناثل أسئلة من أداة المقابلة لتسهيل فههها. وتم التحقق من الثبات عن طريق إعادة التطبيق مرة أخرى بعد مرور فترة

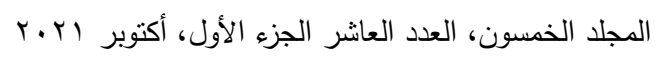

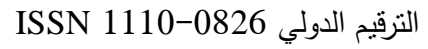

$$
\begin{aligned}
& \text { الترقيم الدولي الموحد الإلكتروني 3178-2636-26 }
\end{aligned}
$$


زمنية بلغت خمسة عشر يوماً من اجابتيهما عليها، وتم حساب معامل الثبات والذي أظهر

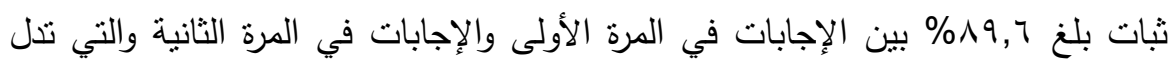
على عدم وجود اختلافات كبيرة في إجابات المبحونات الإنات

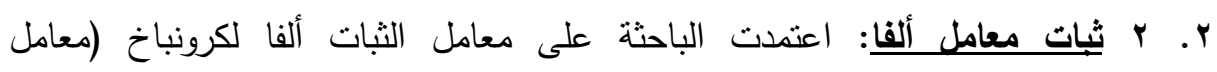
الاعتمادية) لقياس مدى التجانس بين عبارات المقياس، وأظهرت نتائج النحليل والتي لكاتي

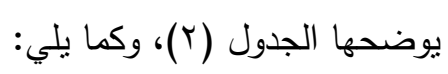



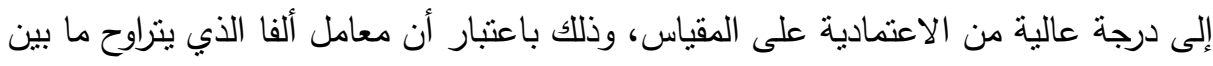

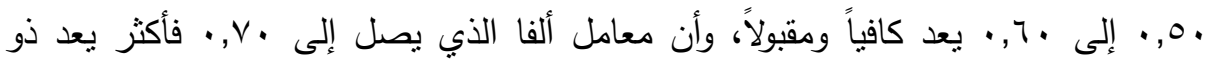
مستوى ممتاز من النقة والاعتمادية.

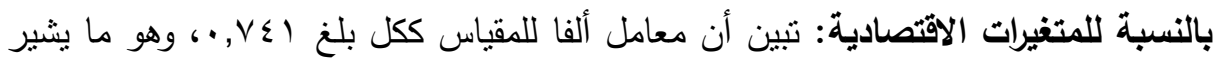
إلى درجة عالية من الاعتمادية على المقياس.

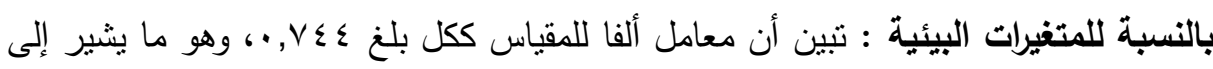
درجة عالية من الاعتمادية على المقياس. جدول رقم (1): نتائج اختبار الثبات لمتغبرات الدراسة

\begin{tabular}{|c|c|c|}
\hline معامل آلفا & عدد العبارات & المقاييس \\
\hline$\cdot, \vee \vee \wedge O$ & 1. & المتغيرات الاجتماعية \\
\hline$\cdot, V \leqslant 1$ & 11 & المتغيرات الاقتصادية \\
\hline$\cdot, V \leqslant \leqslant$ & 7 & المتغيرات البيئية \\
\hline$\cdot, \mathrm{VOV}$ & YV & الهتغيرات ككل \\
\hline
\end{tabular}

المعالجة الإحصائية للبيانات: بعد الانتهاء من جمع البيانات اللازمة للاراسة، تم إدخالها -بعد ترميزها- إلى الحاسب الآلي ثم جرت معالجتها وتحليلها واستخراج النتائج الإحصائية

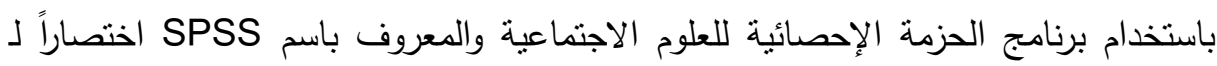
106

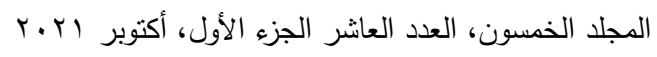

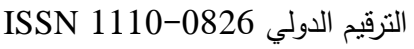

$$
\begin{aligned}
& \text { التزقيم الدولي الموحد الإلكتروني 3178-2636-2 }
\end{aligned}
$$


مجلة العلوم البيئية

كلية الدراسات العليا والبحوث البيئية - جامعة عين شمس لئن

حنان كامل فريد وآخرون

Statistical package for social sciences (version 23)

المعاملات والاختبارات والمعالجات الإحصائية التالية:

$$
\text { 1. التكرارات البسيطة والنسب المئوية. }
$$

r. المتوسطات الحسابية والانحرافات المعيارية.

r. اختبار كاr.

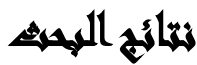

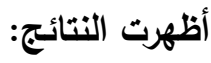

1-متغير العمر كان له أثز ايجابي علي توجه المرأة الي المشروعات متتاهية الصغر في



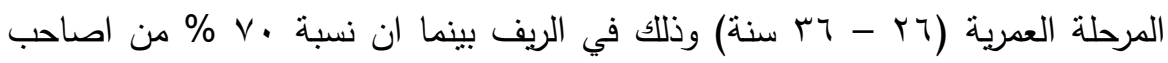

المشروعات تقع في المرحلة العمرية ( بr - جr سنة)، وكلما زاد أو قل السن عم هذه

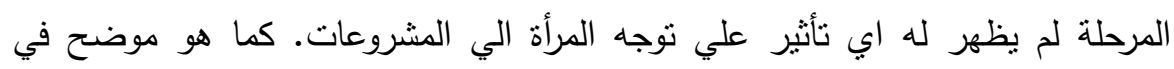

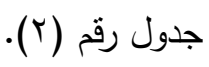

جدول (r): (r) (x)

\begin{tabular}{|c|c|c|c|c|c|c|c|c|c|c|c|}
\hline \multicolumn{6}{|c|}{ الحضر } & \multicolumn{6}{|c|}{ الريف } \\
\hline \multicolumn{2}{|c|}{ V - أكبر } & \multicolumn{2}{|c|}{$r q-r q$} & \multicolumn{2}{|c|}{ اقل من } & \multicolumn{2}{|c|}{ V - اكبر - آ } & \multicolumn{2}{|c|}{ q } & \multicolumn{2}{|c|}{ اقل من من } \\
\hline النسبة & العدد & النسبة & العدد & النسبة & العدد & النسبة & العدد & النسبة & العدد & النسبة & العدد \\
\hline 10 & 1 & $\begin{array}{l}V . \\
\%\end{array}$ & $V$ & $\%$ r. & $Y$ & 10 & 1 & $\begin{array}{l}0 . \\
\%\end{array}$ & 0 & $\% \leq$. & $\varepsilon$ \\
\hline
\end{tabular}

r - متغير مستوي التعليم كان له تأثير ايجابي علي توجه المرأة الي المشروعات متتاهية

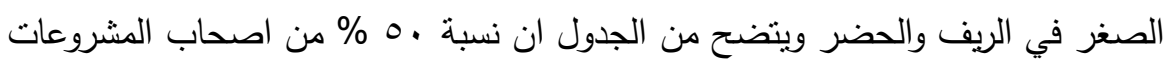



$$
\begin{aligned}
& \text { المجلد الخمسون، العدد العاثر الجزء الأول، أكتوبر اب.r.T } \\
& \text { الترقيم الدولي 0826-0 1110 } \\
& \text { الترقيم الدولي الموحد الإلكتروني 3178-2636-26 }
\end{aligned}
$$


المشروعات تقع في مرحلة التعليم فوق المتوسط ، فكلما زاد مستوي التعليم في الحضر زاد

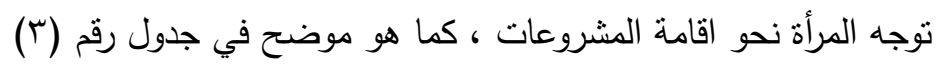

جدول (ץ):

\begin{tabular}{|c|c|c|c|c|c|c|c|c|c|c|c|}
\hline \multicolumn{6}{|c|}{ العضر } & \multicolumn{6}{|c|}{ الريف } \\
\hline \multicolumn{2}{|c|}{ تعليم فوق المتوسط } & \multicolumn{2}{|c|}{ تعليم متوسط } & \multicolumn{2}{|c|}{ امي } & \multicolumn{2}{|c|}{ تعليم فوق المتوبط } & \multicolumn{2}{|c|}{ تعليم متوسط } & \multicolumn{2}{|c|}{ امي } \\
\hline النسبة & العدد & النسبة & العدد & النسبة & العدد & النسبة & العدد & النسبة & العدد & النسبة & العدد \\
\hline$\% \wedge$ & $\wedge$ & $\begin{array}{l}r . \\
\%\end{array}$ & r & - & - & $\% 1$. & 1 & $\begin{array}{l}0 . \\
\%\end{array}$ & 0 & $\begin{array}{l}\varepsilon . \\
\%\end{array}$ & $\varepsilon$ \\
\hline
\end{tabular}

r- متغير الحالة الاجتماعية كان له تأثنر متوسط على توجه المرأة الي المشروعات متتاهية

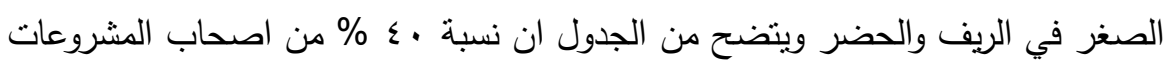

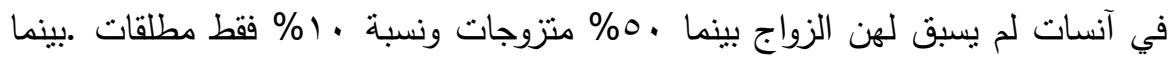

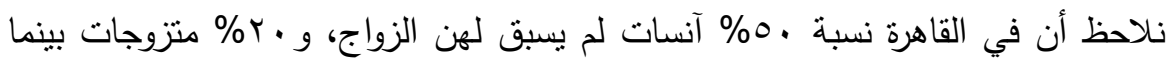
نسبة . بـ\% من السيدات مطلقات.



\begin{tabular}{|c|c|c|c|c|c|c|c|c|c|c|c|}
\hline \multicolumn{6}{|c|}{ الحضر } & \multicolumn{6}{|c|}{ الريف } \\
\hline \multicolumn{2}{|c|}{ مطلقة } & \multicolumn{2}{|c|}{ متزوجة } & \multicolumn{2}{|c|}{ انسة } & \multicolumn{2}{|c|}{ مطلقة } & \multicolumn{2}{|c|}{ متزوجة } & \multicolumn{2}{|c|}{ أنسة } \\
\hline النسبة & العدد & النسبة & العدد & النسبة & العدد & النسبة & العدد & النسبة & العدد & النسبة & العدد \\
\hline$\%$ \%. & r & $\%$ \%. & $r$ & $\% 0$. & 0 & $\% 1$. & 1 & $\% 0$. & 0 & $\%$ \%. & $\varepsilon$ \\
\hline
\end{tabular}



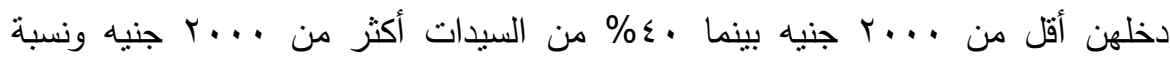

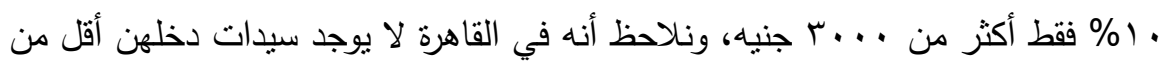

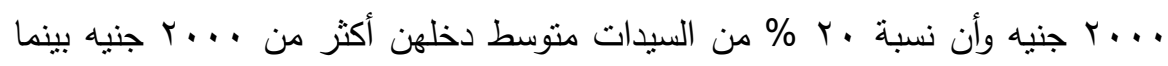

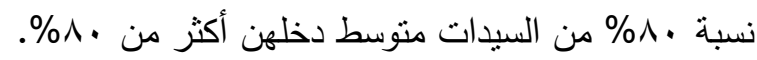

$$
\begin{aligned}
& \text { المجلد الخمسون، العدد العاثر الجزء الأول، أكتوبر ابr.r. } \\
& \text { التزقيم الدولي 0826- ISSN 1110 } \\
& \text { الترقيم الدولي الموحد الإلكتروني 3178-2636-26 التربي }
\end{aligned}
$$


مجلة العلوم البيئية - مالية

كلية الدراسات العليا والبحوث البيئية - جامعة عين شس البئ

حنان كامل فريد وآخرون

جدول (0): - 1) - 1)

\begin{tabular}{|c|c|c|c|c|c|c|c|c|c|c|c|}
\hline \multicolumn{6}{|c|}{ الحضر } & \multicolumn{6}{|c|}{ الريف } \\
\hline \multicolumn{2}{|c|}{ 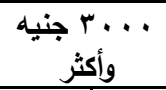 } & \multicolumn{2}{|c|}{ 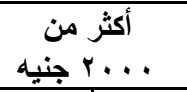 } & \multicolumn{2}{|c|}{.... . ج جنيه } & \multicolumn{2}{|c|}{ 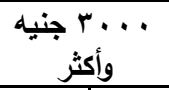 } & \multicolumn{2}{|c|}{ أكثر من . . . . جنيه } & \multicolumn{2}{|c|}{. . . . جنيه } \\
\hline النسبة & العدد & النسبة & العدد & النسبة & العدد & النسبة & العدد & النسبة & العدد & النسبة & العدد \\
\hline$\% \wedge$. & $\wedge$ & $\% r$. & $r$ & - & - & $\% 1$. & 1 & $\% \varepsilon$. & $\varepsilon$ & $\begin{array}{l}0 . \\
\%\end{array}$ & 0 \\
\hline
\end{tabular}

جدول (†): نتائج نوع المشروع

\begin{tabular}{|c|c|c|c|c|c|c|c|}
\hline \multicolumn{2}{|c|}{ الحضر } & \multirow{2}{*}{ 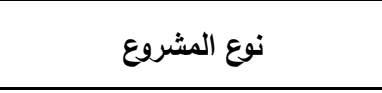 } & \multirow{2}{*}{ رقالة } & \multicolumn{2}{|c|}{ الريف } & \multirow{2}{*}{ 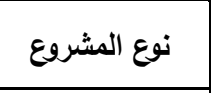 } & \multirow{2}{*}{ رقاثة } \\
\hline النسبة & 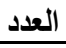 & & & النسبة & 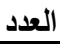 & & \\
\hline $1 \cdot, \cdot$ & 1 & تجارة سلع ومنتجات مستوردة من أدوات منزلية. & 1 & $r_{\cdot}, \cdot$ & r & تلي ومنسسج & r. \\
\hline $1 \cdot, \cdot$ & 1 & مشغولات يدوية هاند ميد & r & $1 \cdot, \cdot$ & 1 & مخبوزات وطعام & $r$ \\
\hline $1 \cdot, \cdot$ & 1 & ادوات منزليه وكل ما يخص البيت & $r$ & $r_{\cdot, \cdot}$ & r & تخريز تراثى تلي & 0 ، \\
\hline $1 \cdot, \cdot$ & 1 & حلويات غربية وشرقية وكعك & $\varepsilon$ & $r_{\cdot, \cdot}$ & $r$ & أكسبوارات حريمي & 7 \\
\hline $1 \cdot, \cdot$ & 1 & تجهيز أكلات وأطعمة & 0 & $r_{\cdot, \cdot}$ & $r$ & أكسوارات منزلية & $1 \cdot 6$ \\
\hline $1 \cdot, \cdot$ & 1 & مستحضرات تجميل طبيعية & 7 & $1 \cdot, \cdot$ & 1 & كل أنواع الخياطة & $\wedge$ \\
\hline $1 \cdot, \cdot$ & 1 & اكسسوارات شخصية ومنزلية & V & & & & \\
\hline $1 \cdot, \cdot$ & 1 & واكسسوارات منزلية منتجات يدوية & $\wedge$ & & & & \\
\hline $1 \cdot, \cdot$ & 1 & مشروع منتجات جلدية بدوية & 9 & & & & \\
\hline $1 \cdot, \cdot$ & 1 & 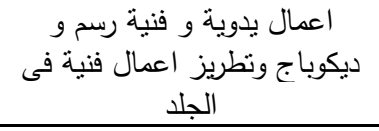 & 1. & & & & \\
\hline $1 \cdots$ & 1. & الإجمالي & & $1 \cdots$ & 1. & الإجمالي & \\
\hline
\end{tabular}

المجلد الخمسون، العدد العاثر الجزء الأول، أكتوبر ابr.r.

التزقيم الدولي 0826- ISSN 1110

الترقيم الدولي الموحد الإلكتروني 3178-2636-26 التروب 
يوضح الجدول السابق توزيع عينة الدراسة تبعاً لنوع المشروع والذي يتضح من خلاله أن الن النيا

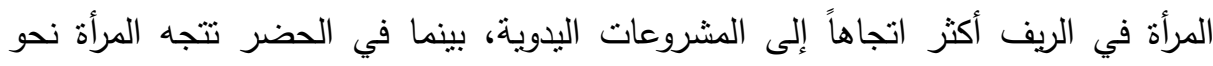
المشروعات التي تعتمد على البيع وليس الإنتاج.

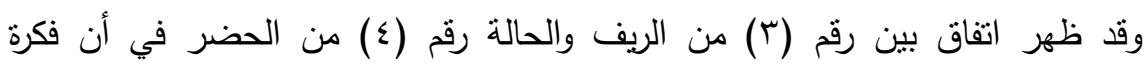

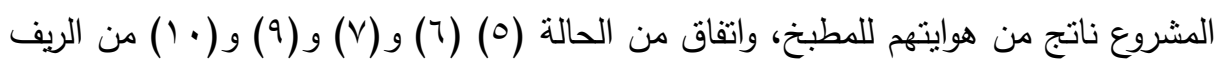
والحالة رقم (r) أن فكرة المشروع ناتج من حبهم للمشغولات اليدوية، بينما اختلفت باقي الحالات في الفكرة. جدول (V): الوجود ممول أخر للمشروع

\begin{tabular}{|c|c|c|c|c|c|c|c|}
\hline \multirow[t]{2}{*}{ Is } & \multicolumn{2}{|c|}{ إجمالي العينة } & \multicolumn{2}{|c|}{ الحضر } & \multicolumn{2}{|c|}{ الريف } & \multirow[t]{2}{*}{ الإجابة } \\
\hline & النسبة & العدد & النسبة & العدد & النسبة & العدد & \\
\hline \multirow[t]{3}{*}{ 1,.0r } & 90 & 19 & 9. & 9 & $1 \ldots$ & 1. & $\gamma$ \\
\hline & 0 & 1 & 1. & 1 & . & . & نعم \\
\hline & $\% 1, \ldots$, & $r$. & $1 \ldots$ & 1. & $1 \ldots$ & 1. & الإجمالي \\
\hline
\end{tabular}

يوضح الجدول السابق نتائج إجابات عينة الدراسة على التساؤل هل يوجد ممول غيرك

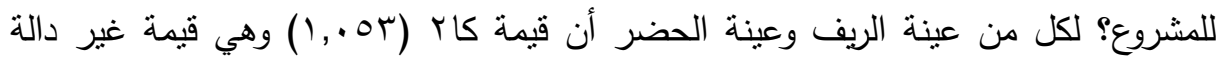

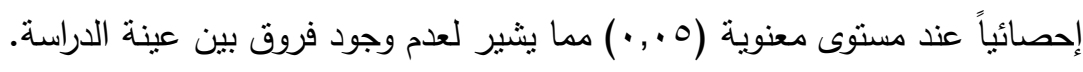



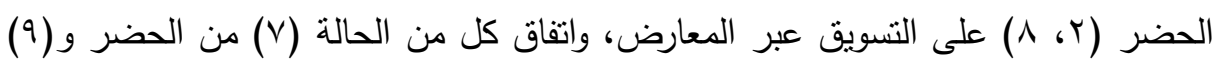

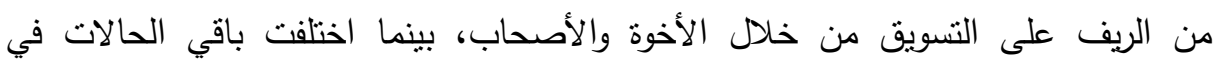

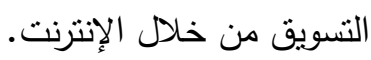


مجلة العلوم البيئية

كلية الدراسات العليا والبحوث البيئية - جامعة عين شمس لئن

حنان كامل فريد وآخرون

جدول (^): مدى إرتباط المشروع بالبيئة المقام عليها

\begin{tabular}{|c|c|c|c|c|c|c|c|}
\hline \multirow{2}{*}{ كا' } & \multicolumn{2}{|c|}{ إجمالي العينة } & \multicolumn{2}{|c|}{ الحضر } & \multicolumn{2}{|c|}{ الريف } & \multirow{2}{*}{ الإجابة } \\
\hline & النسبة & العدد & النسبة & العدد & النسبة & العدد & \\
\hline \multirow{3}{*}{$1,9 \vee \wedge$} & ro & v & 0. & 0 & r. & $r$ & غير مرتبط \\
\hline & 70 & $1 \pi$ & 0. & 0 & $\Lambda$. & $\wedge$ & مرتط \\
\hline & $\% 1, \ldots$, & $r$. & $1 \ldots$ & 1. & $1 \ldots$ & 1. & الإجمالي \\
\hline
\end{tabular}

يوضح الجدول السابق نتائج إجابات عينة الدراسة على مدي إرتباط المشروع بالبيئة

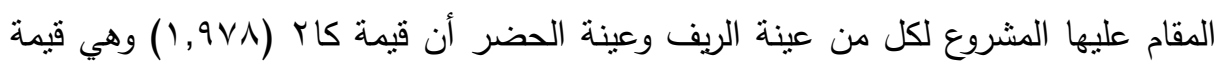
غير دالة إحصائياً عند مستوى معنوية (0. . • ) مما يشير لعدم وجود فروق بين عينة الدراسة.

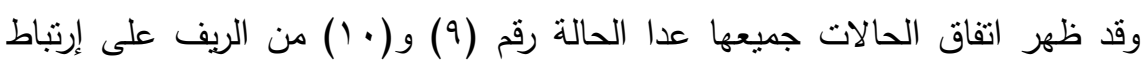



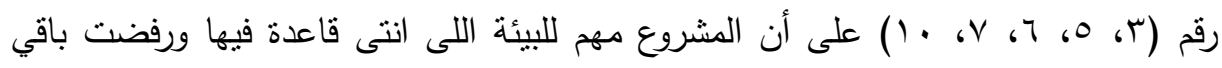

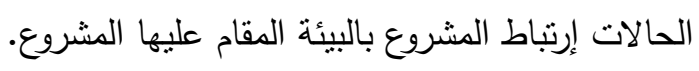

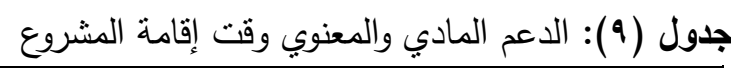

\begin{tabular}{|c|c|c|c|c|c|c|c|}
\hline \multirow{2}{*}{ sis } & \multicolumn{2}{|c|}{ إجمالى العينة } & \multicolumn{2}{|c|}{ الحضر } & \multicolumn{2}{|c|}{ الريف } & \multirow{2}{*}{ الإجابة } \\
\hline & النسبة & العدد & النسبة & العدد العداد & النسبة & العدد & \\
\hline \multirow{5}{*}{$r, r \ldots$} & r. & $\varepsilon$ & $r$. & r & $r$. & r & لا يوجد دعم معنوى أو \\
\hline & so & 9 & $r$. & $\Gamma$ & $\pi$. & $\frac{7}{9}$ & دعم معنوى \\
\hline & 1. & r & r. & r & . & . & دعم مادى \\
\hline & ro & 0 & $r$. & $\bar{r}$ & $r$. & $r$ & دعم معنوى ومادى \\
\hline & $\% 1, .$, & $r$. & $1 \ldots$ & 1. & $1 \ldots$ & 1. & الإجمالي \\
\hline
\end{tabular}

يوضح الجدول السابق نتائج إجابات عينة الدراسة عن الدعم المادي والمعنوي التي

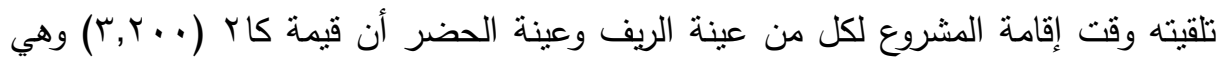

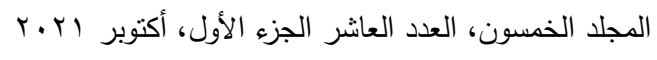

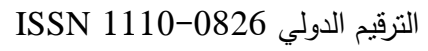

$$
\begin{aligned}
& \text { الترقيم الدولي الموحد الإلكتروني 3178-2636 }
\end{aligned}
$$


قيمة غير دالة إحصائياً عند مستوى معنوية (0., •) مما يشير لعدم وجود فروق بين عينة الدراسة.

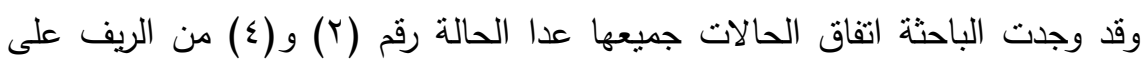

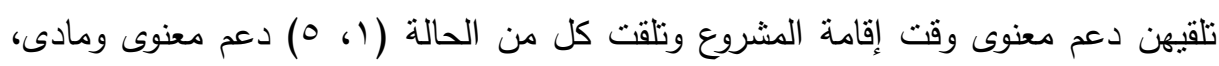

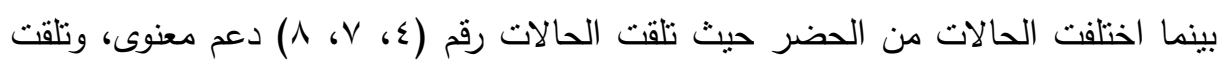

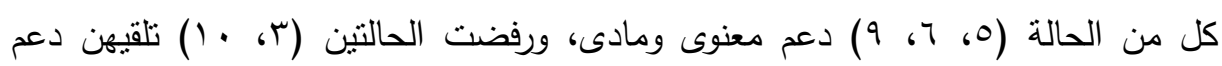

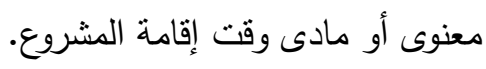

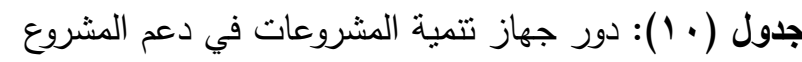

\begin{tabular}{|c|c|c|c|c|c|c|c|}
\hline \multirow{2}{*}{ كاי } & \multicolumn{2}{|c|}{ إجمالي العينة } & \multicolumn{2}{|c|}{ الحضر } & \multicolumn{2}{|c|}{ الريف } & \multirow{2}{*}{ الإجابة } \\
\hline & النسبة & العدد العدا & النسبة & العدد ال العد ال & النسبة & العدد ال العداد & \\
\hline \multirow{3}{*}{$\cdot, \cdots$} & r. & $\varepsilon$ & r. & $r$ & r. & $r$ & لا يوجد دور \\
\hline & A. & 17 & A. & $\wedge$ & A. & $\wedge$ & يوجد دور \\
\hline & $\% 1, .$, & $r$. & $1 \ldots$ & 1. & $1 \ldots$ & 1. & الإجمالي \\
\hline
\end{tabular}

يوضح الجدول السابق نتائج إجابات عينة الدراسة لدور جهاز تتمية المشروعات في دعم

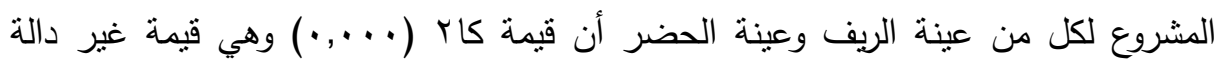

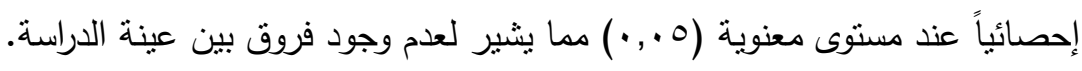

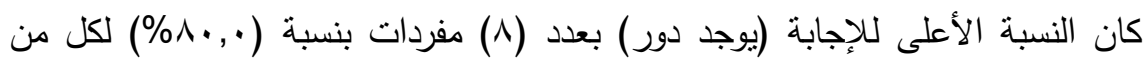



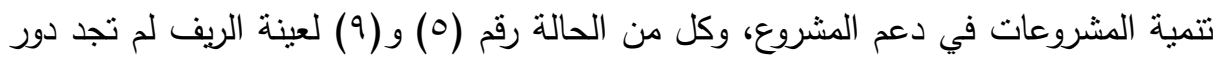
لجهاز تتمية المشروعات في دعم المشروع. 
مجلة العلوم البيئية - مالية

كلية الدراسات العليا والبحوث البيئية - جامعة عين شس البئ

حنان كامل فريد وآخرون

جلول (11): دور الجمعيات الأهلية في دعم المشروع

\begin{tabular}{|c|c|c|c|c|c|c|c|c|c|}
\hline \multirow{2}{*}{ كا' } & \multicolumn{2}{|c|}{ إجمالي العينة } & \multicolumn{2}{|c|}{ الحضر } & \multirow{2}{*}{ رلحالة } & \multicolumn{2}{|c|}{ الريف } & \multirow{2}{*}{ رقم الحالة } & \multirow{2}{*}{ الإجابة } \\
\hline & النسبة & العدد العد & النسبة & العدد العد & & النسبة & العدد الع ال & & \\
\hline \multirow{5}{*}{$T, T Y \varepsilon$} & ro & v & r. & r & 760 & 0. & 0 & \&، & لا أعرف \\
\hline & $r$. & $\varepsilon$ & $r$. & r & $1 \cdot .9$ & r. & $r$ & $1 \cdot r$ & لا ل يوجد \\
\hline & r. & 7 & $\varepsilon$. & $\varepsilon$ & $\begin{array}{l}r, r \\
\Lambda, r\end{array}$ & r. & r & ^ ، 1 & يوجد دور \\
\hline & 10 & r & r. & r & $V$ ، & 1 . & 1 & $r$ & 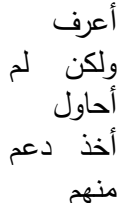 \\
\hline & $\% 1, \ldots$, & $r$. & $1 \ldots$ & 1. & & $1 \ldots$ & 1. & & الإجمالى \\
\hline
\end{tabular}

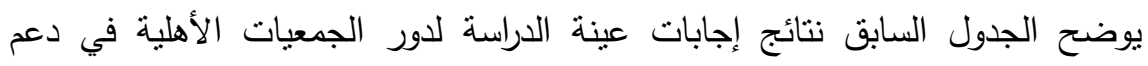

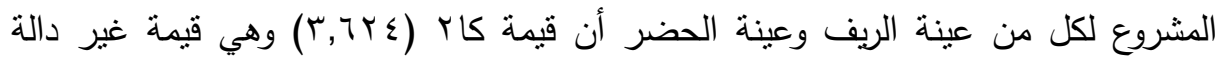

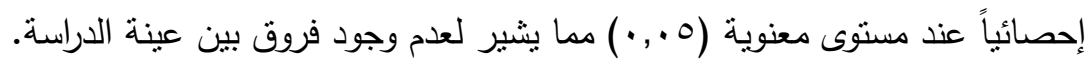
جلول (r ( ): دور المجلس المحلي في دعم المشروعات الصغيرة

\begin{tabular}{|c|c|c|c|c|c|c|c|c|c|}
\hline \multirow{2}{*}{ كاי } & \multicolumn{2}{|c|}{ إجمالي العينة } & \multicolumn{2}{|c|}{ الحضر } & \multirow{2}{*}{ الحالية } & \multicolumn{2}{|c|}{ الريف } & \multirow{2}{*}{ الحالة } & \multirow{2}{*}{ الإجابة } \\
\hline & النسبة & العدد الع ال الم & النسبة & 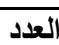 & & النسبة &  & & \\
\hline \multirow{4}{*}{, Yイ } & 7. & IT & 7. & 7 & 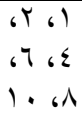 & 7. & 7 & 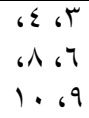 & $\gamma$ \\
\hline & $r$. & $\varepsilon$ & $r$. & $r$ & $V_{\text {V.r }}$ & $r$. & $r$ & 0.1 & نعم \\
\hline & $r$. & $\varepsilon$ & r. & $r$ & 960 & $r$. & $r$ & $V_{6}, r$ & لا أهتم \\
\hline & $\% 1 \ldots$, & $r$. & $1 \ldots$ & 1. & & $1 \ldots$ & 1. & & الإجمالي \\
\hline
\end{tabular}

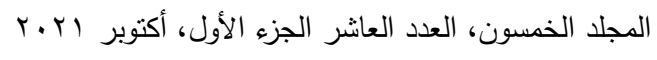

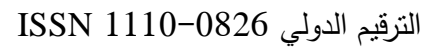

الترقيم الدولي الدوحد الإلكتروني 3178-2636-26 
مجلة العلوم البيئية

كلية الدراسات العليا والبحوث البيئة - جامعة عين شمس البئ

حنان كامل فريد وآخرون

يوضح الجدول السابق نتائج إجابات عينة الدراسة عن نتائج إجابات عينة الدراسة لدور

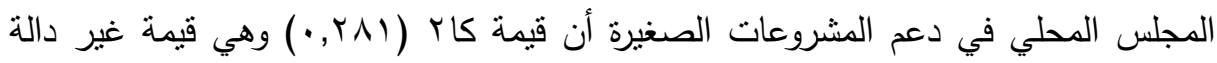

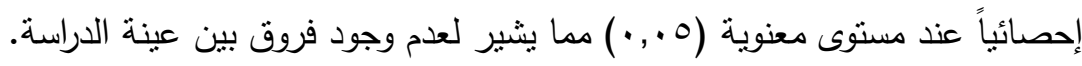

\begin{tabular}{|c|c|c|c|c|c|c|c|c|c|}
\hline & & & \multirow{2}{*}{\multicolumn{2}{|c|}{ الحضر }} & \multirow{3}{*}{ رقلة } & \multirow{2}{*}{\multicolumn{2}{|c|}{ الريف }} & \multirow{3}{*}{ رقم الحالة } & \multirow{3}{*}{ الإجابة } \\
\hline \multirow{2}{*}{ كا' } & \multicolumn{2}{|c|}{ إجمالي العينة } & & & & & & & \\
\hline & النسبة & 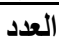 & النسبة & العدد ال العد & & النسبة &  & & \\
\hline \multirow{4}{*}{ "ד, } & $r$. & 7 & 0. & 0 & 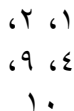 & 1. & 1 & $\wedge$ & V \\
\hline & ro & V & $\varepsilon$. & $\varepsilon$ & $\begin{array}{l}\text { ד، } \\
\\
\end{array}$ & $r$. & $r$ & r، ד، 9 & لا أعرف \\
\hline & ro & V & 1. & 1 & $\wedge$ & 7. & 7 & 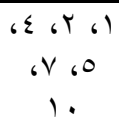 & نعم \\
\hline & $\% 1 \ldots$, & $r$. & $1 \ldots$ & 1. & & $1 \ldots$ & 1. & & الإجمالي \\
\hline
\end{tabular}

يوضح الجدول السابق نتائج إجابات عينة الدراسة عن نتائج إجابات عينة الدراسة عن


عند مستوى معنوية (0 . • ) مما يشير لوجود فروق بين عين عينة الدراسة. 
مجلة العلوم البيئية

كلية الدراسات العليا والبحوث البيئة - جامعة عين شمس البئ

حنان كامل فريد وآخرون

جدول (ء ا): عن توجه الدولة للتيسير علي رائدات الأعمال

\begin{tabular}{|c|c|c|c|c|c|c|c|c|c|}
\hline \multirow{2}{*}{ كا" } & \multicolumn{2}{|c|}{ إجمالي العينة } & \multicolumn{2}{|c|}{ الحضر } & \multirow{2}{*}{ رلحالة } & \multicolumn{2}{|c|}{ الريف } & \multirow{2}{*}{ رقم الحالة } & \multirow{2}{*}{ الإجابة } \\
\hline & النسبة & العدد & النسبة & العدد & & النسبة & العدد العداد العاد & & \\
\hline \multirow{4}{*}{ "T } & r. & $\varepsilon$ & $\varepsilon$. & $\varepsilon$ & $\begin{array}{l}6.61 \\
1.69\end{array}$ & - & - & & $\bar{y}$ \\
\hline & ro & 0 & r. & $r$ & ، 10 & $r$. & r & A r & لا أعرف \\
\hline & 00 & 11 & $r \cdot$ & $r$ & $\begin{array}{c}4 \\
1 \\
1\end{array}$ & ᄉ. & $\wedge$ & 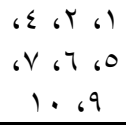 & نعم \\
\hline & $\% 1 \ldots$, & $r$. & $1 \ldots$ & 1. & & $1 \ldots$ & 1. & & الإجمالي \\
\hline
\end{tabular}

يوضح الجدول السابق نتائج إجابات عينة الدراسة عن نتائج إجابات عينة الدراسة عن

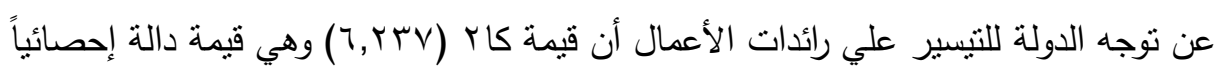
عند مستوى معنوية (0. . •) مما يشير لوجود فروق بين عينة الدراسة.

\begin{tabular}{|c|c|c|c|c|c|c|c|}
\hline \multirow{2}{*}{ كا' } & \multicolumn{2}{|c|}{ إجمالي العينة } & \multicolumn{2}{|c|}{ الحضر } & \multicolumn{2}{|c|}{ الريف } & \multirow{2}{*}{ الإجابة } \\
\hline & النسبة & العدد & النسبة & العدد & النسبة & العدد & \\
\hline \multirow{3}{*}{$r, r \vee \wedge$} & ro & $\mathrm{v}$ & 0. & 0 & $r$. & $r$ & لا يؤثز \\
\hline & 70 & $1 \pi$ & 0. & 0 & A. & $\Lambda$ & يوئثر \\
\hline & $\% 1 \cdots$, & $r$. & $1 \ldots$ & 1. & $1 \ldots$ & 1. & الإجمالي \\
\hline
\end{tabular}

يوضح الجدول السابق نتائج إجابات عينة الدراسة عن نتائج إجابات عينة الدراسة عن


عند مستوى معنوية (0. . • ) مما يشير لعدم وجود فروق بين عينة انئة الدراسة.

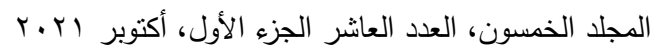



$$
\begin{aligned}
& \text { الترقيم الدولي الموحد الإلكتروني 3178-2636-26 }
\end{aligned}
$$


مجلة العلوم البيئية

كلية الدراسات العليا والبحوث البيئية - جامعة عين شمس لبه

حنان كامل فريد وآخرون

جدول (7 ( ): مدى تأثز المشروع بأزمة الكورونا

\begin{tabular}{|c|c|c|c|c|c|c|c|c|c|}
\hline \multirow[t]{2}{*}{ Sis } & \multicolumn{2}{|c|}{ إجمالي العينة } & \multicolumn{2}{|c|}{ الحضر } & \multirow{2}{*}{ رالحالة } & \multicolumn{2}{|c|}{ الريف } & \multirow{2}{*}{ رالحالة } & \multirow[t]{2}{*}{ الإجابة } \\
\hline & النسبة & العدد & النسبة & العدد & & النسبة & العدد & & \\
\hline \multirow[t]{5}{*}{$r, \tau \ldots$} & 0 & 1 & 1. & 1 & 1 & . & . & & لم بتأثر \\
\hline & r. & 7 & $\varepsilon$. & $\varepsilon$ & $\begin{array}{l}670 \\
\wedge, V\end{array}$ & $r$. & r & 967 & تأثز ما إلى ما \\
\hline & 0. & 1. & $r$. & $r$ & $\begin{array}{c}.96 \\
1.4\end{array}$ & $\vee \cdot$ & V & 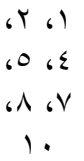 & تأتزر \\
\hline & 10 & $r$ & $r$. & $r$ & $\varepsilon, T$ & 1. & 1 & $r$ & تأأثر \\
\hline & $\% 1 \ldots$, & $r$. & $1 \ldots$ & 1. & & $1 \ldots$ & 1. & & الإجمالي \\
\hline
\end{tabular}

يوضح الجدول السابق نتائج إجابات عينة الدراسة عن نتائج إجابات عينة الدراسة عن

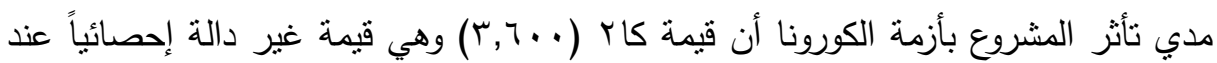
مستوى معنوية (0. . • ) مما يشير لعدم وجود فروق بين عينة الدراسة. جدول (IV): مدى وجود دعم من الحكومة للمشروع

\begin{tabular}{|c|c|c|c|c|c|c|c|}
\hline \multirow[t]{2}{*}{ Sا } & \multicolumn{2}{|c|}{ إجمالي العينة } & \multicolumn{2}{|c|}{ الحضر } & \multicolumn{2}{|c|}{ الريف } & \multirow[t]{2}{*}{ الإجابة } \\
\hline & النسبة & العدد & النسبة & العدد & النسبة & العدد & \\
\hline \multirow[t]{5}{*}{$\varepsilon, r \cdot \Lambda$} & ro & V & $r$. & $r$ & 0. & 0 & لم تجيب \\
\hline & ro & V & $\varepsilon$. & $\varepsilon$ & $r$. & r & ע \\
\hline & 0 & 1 & 1. & 1 & . & . & إلى حد ما \\
\hline & ro & 0 & r. & $r$ & $r$. & $r$ & نعم \\
\hline & $\% 1, \cdot$, & $r$. & $1 \ldots$ & 1. & $1 \ldots$ & 1. & الإجمالي \\
\hline
\end{tabular}

يوضح الجدول السابق نتائج إجابات عينة الدراسة عن نتائج إجابات عينة الدراسة عن

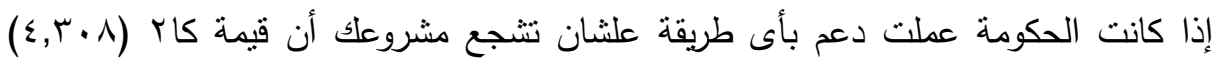

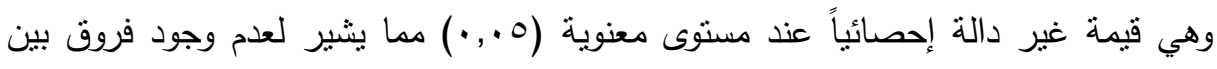

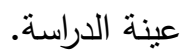

116

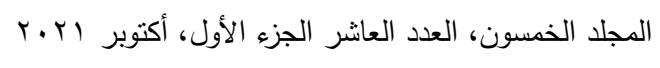

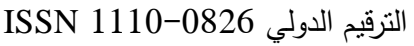
الترقيم الدولي الموحد الإلكتروني 3178-2636 
وتتفق نتائج الدراسة الحالية مع نتائج عدد من الدراسات السابقة والتي من بينها: دراسة (Tamer Mansour \& et.al, 2019) والتي أثنار من خلالها إلى وجود علاقة لئه بين المتغيرات الديموغرافية وبين التوجه نحو المشروعات الصغيرة. كذلك الأمر نفسه بالنسبة لدراسة (Rym Ayadi \& et.al, 2017) وأكدت الدراسة على أهمية المشروعات المتتاهية الصغر والصغيرة والمتوسطة وأنها أصبحت أولوية سياسية في دول شرق وجنوب البحر البحر المتوسط التي تعاني من البطالة.

واتفقت دراسة (Hala El-Said, et.al 2014) مع ما نوصلت إليه النتائج السابقة وأثنارت إلى أن المؤسسات الصغيرة والمتوسطة الحجم تمثل قوة ديناميكية للنمو الاقتصادي المستدام.

أما دراسة (Jasika Alam Jitu, 2019) فقد أكدت على العلاقة القوية بين توجه المرأة نحو المشروعات الصغيرة ومتتاهية الصغر والعوامل الديموغرافية لعينة الدراسة خاصة

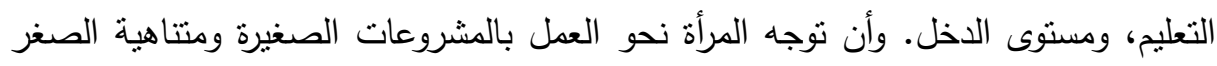
ترك الكثير من النتائج الإيجابية على مستوى دخل الأسرة وحجم الانفاق، وعلى تمكين المرأة

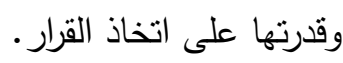

\section{التهوصياهت}

\section{من أهم توصيات الاراسة:}

() توصي الدراسة الحالية بضرورة تفعيل السياسات والإجراءات التي تتجع المرأة على إقامة

$$
\text { مشروعاتهن الخاصة. }
$$

r) كما توصي بضرورة التوسع في مشروعات التصنيع الزراعي والتشجيع عليه من خلال وضع برامج تدريبية وتوفير منفذ لبيع تلك المنتجات الزراعية.

$$
\begin{aligned}
& \text { المجلد الخمسون، العدد العاثر الجزء الأول، أكتوبر ابr.r. } \\
& \text { الترقيم الدولي 0826-1110 } \\
& \text { الترقيم الدولي الموحد الإكتروني 3178-2636 }
\end{aligned}
$$


r) وتوصي الدراسة كذلك بزيادة الفرصة لاى المرأة المصرية من أجل المشاركة في سوق العمل على الصعيد العالمي، وتيسير كافة الطرق التي تساعدها في تحقيق ذللك.

ء) كما توصي الدراسة الحالية بضرورة البت بشكل جدي في عملية نطوير سياسات المشتريات العامة والتوريدات بما يضمن نصيبا أكبر لمنتجات المشروعات المتتاهية الصغر والصغيرة المملوكة للمرأة.

0) كما توصي الدراسة كذلك بنسهيل إجراءات حصول المشروعات الصغيرة على القروض وتخفيض فائدتها.

7) وتوصي الدراسة بضرورة وضع القوانين والإجراءات التي تناعد على الحفاظ على حقوق المرأة العاملة في القطاع غير الرسمي، وذللك من خلال أجراء دراسات حول المساهمة الاقتصادية لعمل المرأة غير مدفوع الأجر داخل المنزل، كأساس لنشر ثقافة تثمين هذاء

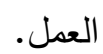

V) وتوصي الدراسة كذلك بضرورة التوسع في خدمات تتمية الأعمال الموجهة للمرأة، وتطبيق نظام الثباك الواحد للمرأة المستثمرة. ^) كما توصي الدراسة بتقديم أنواع مختلفة من التعليم الفني التي تتتاسب واحتياجات المجتمع لمعاد المصري وقدرات المرأة المصرية.

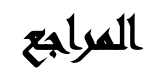



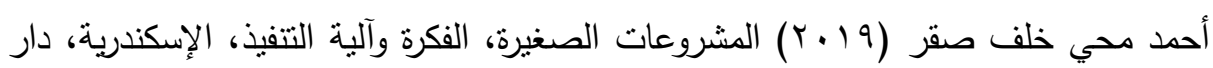
التعليم الجامعي.

اعتماد علام (9 ( ا ب) ريادة الاعمال والمشروعات الصناعية الصغيرة في الريف، القاهرة، دار 118 انجلو للنشر والنوزيع.


التزقيم الدولي 0826- ISSN 1110 الترقيم الدولي الموحد الإلكتروني 3178-2636-26 
جيهان عبد السلام عباس (•r.r.r) دور المشروعات الصغيرة في تحقيق التتمية الاقتصادية

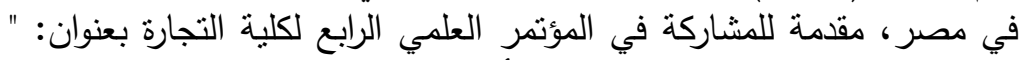

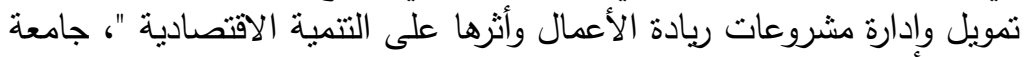
طنطا، كلية الدراسات الإفريقية العليا.

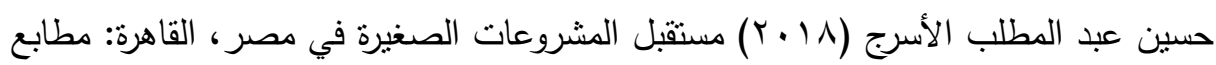
مؤسسة الأهرام.

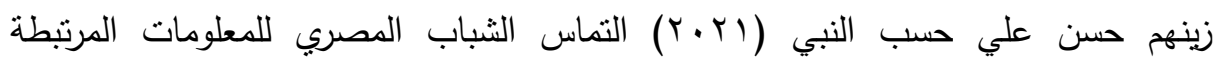

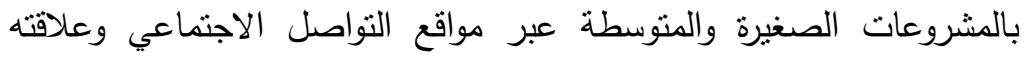

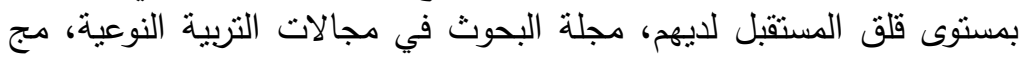

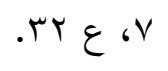

سمر ناصر عبد الوهاب (1) (1) دور رجال الأعمال في التغير الاجتماعي والثقافي بحث

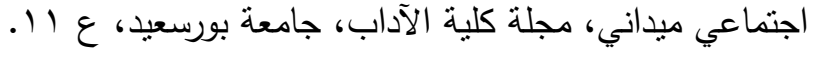

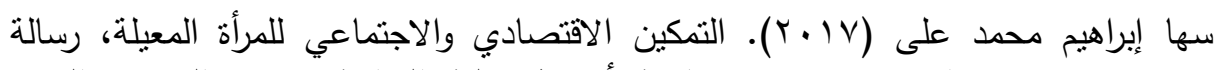



$$
\text { والإرشاد الزراعي. }
$$

شدوان علي شيبة (7 ( ب الإعلان المدخل والنظرية، الإسكندرية: دار المعرفة الجامعية.

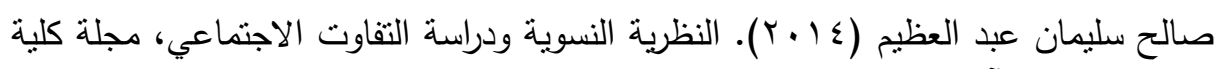

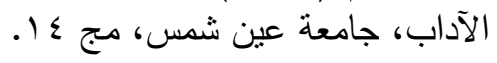

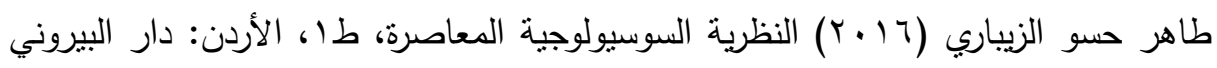
للنشر والتوزيع.

عادل محمد (1991) اتجاهات نظرية في سيكولوجية نمو الطفل والمراهق، القاهرة: مكتبة

$$
\text { الأنجلو المصرية. }
$$

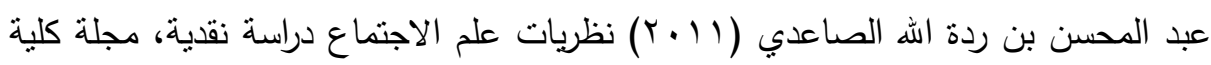



$$
\begin{aligned}
& \text { المجلد الخمسون، العدد العاثر الجزء الأول، أكتوبر ابr.r. }
\end{aligned}
$$

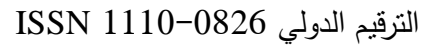

$$
\begin{aligned}
& \text { الترقيم الدولي الموحد الإلكتروني 3178-2636-26 }
\end{aligned}
$$






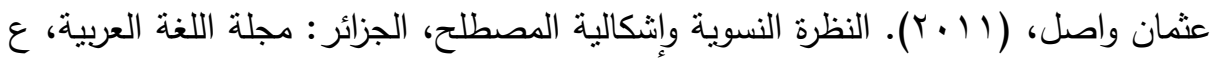

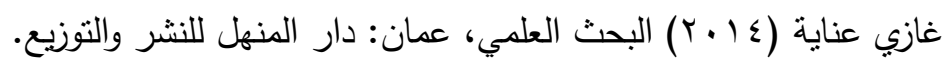

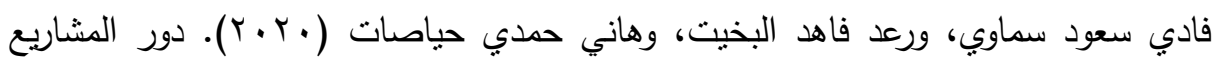

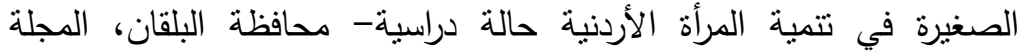

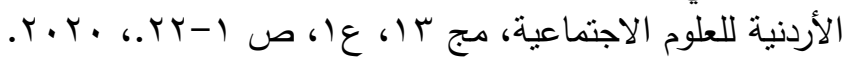

فهر سيف الدين سعاتي (ع (ب). الإدارة الرياضية: مناهج البحث العلمي في الإدارة

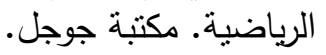



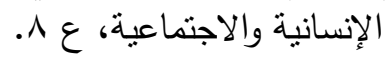

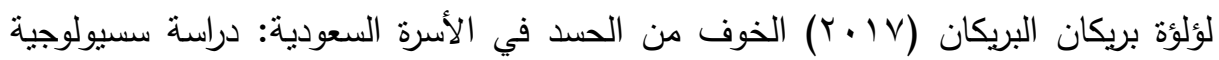



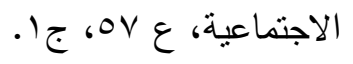

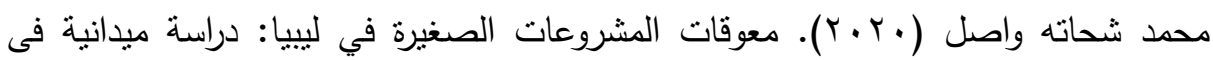

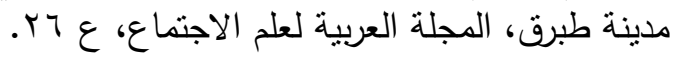

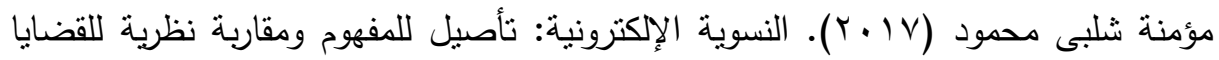
التي يثيرها، مجلة كلية الآداب والعلوم الإنسانية بالإسماعيلية، ع ع. r.

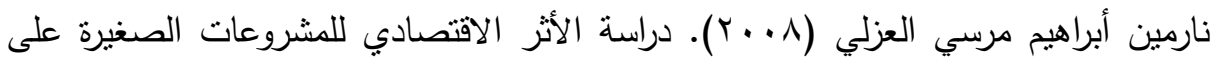


الاقتصاد الزراعي.

ناصر بن حمد العويشق (10) النظرية البنائية وتطبيقاتها في التعليم والتعلم، نسخة

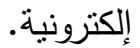

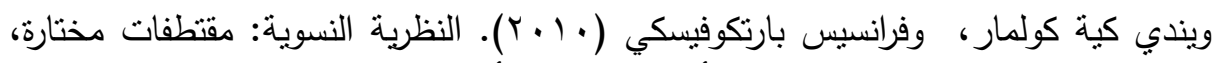
ترجمة: عماد إبراهيم، الأردن: المكتبة الأهلية.

120

$$
\begin{aligned}
& \text { المجلد الخمسون، العدد العانشر الجزء الأول، أكتوبر ب.r.r. }
\end{aligned}
$$

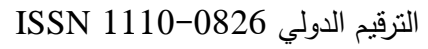

$$
\begin{aligned}
& \text { الترقيم الدولي الموحد الإلكتروني 3178-2636-26 }
\end{aligned}
$$




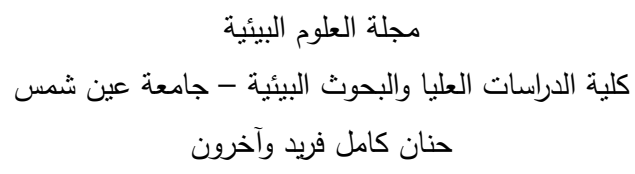

Amjad Ali, et.al. (2014). Role of Small Business Firms in Women Economic Empowerment: A Case Study of Gilgit Baltistan, International Journal of Academic Research in Economics and Management Sciences, Vol.3, No.6.

Blanca Arellano, Josep Roca (2017) "Defining urban and rural areas: a new approach," Remote Sensing Technologies and Applications in Urban Environments II, Vol 10431, No 1.

Bradea \& Z. Kovacs (2014) City and Countryside under WorldWide Urbanization, Regional Research of Russia, Vol 4 , No 2.

Dianne Welsh \& Mariana Dragusin (2013). Women-Entrepreneurs: A Dynamic Force Of Small Business Sector, Amfiteatru Economic, Vol 20.

Gordon Hunter\& Dan Kazakoff (2014) Small Business "Success Growth versus Longevity", Canada: The University of Lethbridge, Faculty of Management, https://www.coursehero.com/file/61408823/art099doc/

Hala El-Said,et.al (2014). Small and Medium Enterprises Landscape in Egypt: New Facts from a New Dataset, Journal of Business and Economics, Vol5, No2.

Jan Servaes (2011) Social Change, OBO Social Change.

- Jasika Alam Jitu (2019). Women Economic Empowerment and SMEs A Case Study on Bangladesh, Master's Thesis, Peace and Development, Linnaus University.

Nurul Asfiah, et.al. (2018). An Analysis of Women Empowerment on Micro Business with Social Entrepreneurship Concept, Conference: 2018 3rd International Conference on Education, Sports, Arts and Management Engineering (ICESAME 2018)

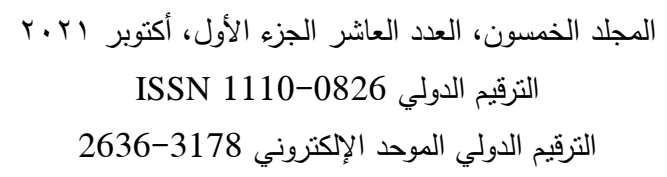




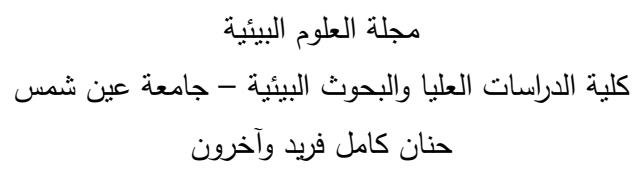

Rym Ayadi \& et.al (2017). Micro, Small and Medium Sized Enterprises Development in Egypt, Jordan, Morocco \& Tunisia Structure, Obstacles And Policies, EMNES Studies.

Tamer G. I. Mansour \& et.al (2018) The Role of Small and Medium Enterprises in Economic Development, Case of Egypt, The International Journal of Business Management and Technology, Vol2, No 5.

Theophilus C Akujobi, (2017) Social Change and Social Problems, Major Themes in Sociology: An Introductory Text, p 491526.

THE IMPACT OF SOME SOCIAL AND

ENVIRONMENTAL VARIABLES FACING WOMAN

IN MICRO PROJECTS

\section{A COMPARATIVE STUDY BETWEEN RURAL AND}

\section{URBAN AREAS}

\section{Hanan K. Farid ${ }^{(1)}$; Saleh S. Abdel Azeem ${ }^{(2)}$; Naglaa M. Mesailhy ${ }^{(2)}$ and Wael F.Abdel Basit ${ }^{(3)}$}

1) Post Grad. Student, Faculty of Graduate Studies and Environmental Research, Ain Shams University 2) Faculty of Arts, Ain Shams University 3) Faculty of Commerce, Ain Shams University

\footnotetext{
ABSTRACT

This research drives at identifying some of the social and environmental variables facing woman in micro projects in both the rural and the urban areas. The study population is Sohag Governorate is 122

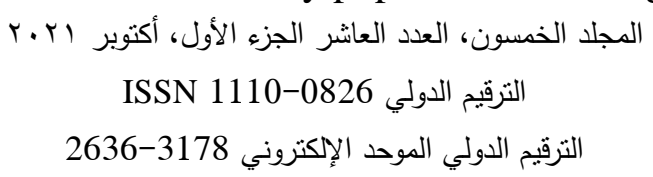




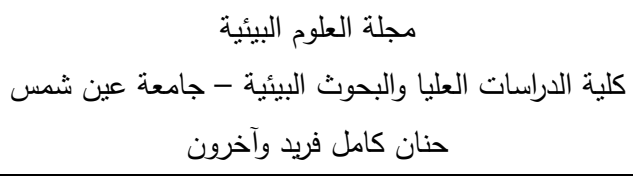

divided into (20) items, (10 cases), representing the rural side) in Cairo Governorate, and (10 cases) representing the urban area). The study use the case study approach for being the most appropriate for the current study. The sample is selected purposely.

The study comes to the following results:

1. The impact of the following variables varies between rural and urban areas regarding age, level of education, marital status, number of family members, average household income, and the extent of spread of micro-enterprises.

2. The study reached a set of recommendations, the most important of which are: the need to consider facilitating loan repayment periods, providing training courses to establish micro-enterprises, state support for these projects represented in local councils, especially, in the countryside, and support women by conducting training courses to market handicraft products locally and internationally.

3. The necessity of providing raw materials for women joining the micro-enterprises.

4. Working on facilitating procedures by making available of loans granted by banks as well as the Enterprise Development Authority, increasing the exhibitions held to market products, whether in rural or urban areas.

5. Working on supporting women in light of the Corona pandemic by scheduling granted loans before the Corona virus period, working on the spread out of the culture of handicrafts in societies.

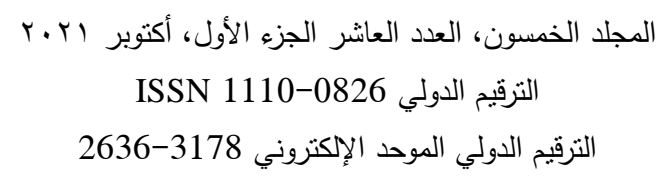

